\title{
COMMUNAL VIOLENCE IN POSO, CENTRAL SULAWESI: WHERE PEOPLE EAT FISH AND FISH EAT PEOPLE
}

\section{Lorraine V. Aragon'}

\section{Tales of Conflict, Politics of Division}

In July 2000, I traveled on a crowded bus south from Central Sulawesi's Muslimmajority capital, Palu, to the Protestant-majority highlands. Protestant and Muslim passengers around me, previously strangers, chatted about the reprehensibility of the violence occurring just two hundred kilometers east in Poso. A Muslim elder on the bus concluded the conversation by saying, "In Palu people eat fish, but in Poso fish eat people" ("Di Palu orang makan ikan tapi di Poso ikan makan orang"). Afterwards, my Protestant companions discussed the phrase. In Palu, things were still good, with people eating the best of all foods, fish. In Poso, things were reversed and unnatural: the corpses of victims had been tossed in the river, their fate to be a meal for fish. It was said that fisherman, while gutting fish from the Gulf of Tomini, north of Poso, had discovered severed hands wearing golden rings.

\footnotetext{
${ }^{1}$ I am grateful to many who shared data related to Poso, including Greg Acciaioli, Timothy Babcock, Jafar Bua, Betty Chandra, Elizabeth Coville, Clark Cunningham, Kevin Evans, Sundjaya, Sidney Jones, Celia Lowe, John MacDougall, Michael Martens, Andrea Molnar, Oren Murphy, Rusli Pasau, David Rohde, Albert Schrauwers, and Esther Veldhoen. I am further indebted to Greg Acciaioli, Robert Hefner, Sidney Jones, David Rohde, and Albert Schrauwers for comments on an early draft, and to Ben Anderson and Deborah Homsher for extensive substantive and editorial suggestions. I also thank conflict symposium colleagues, including Gene Ammarell, Jacques Bertrand, Elizabeth Collins, Robert Hefner, Octovianus Mote, Nancy Peluso, Imam Prasodjo, and Danilyn Rutherford.
} 


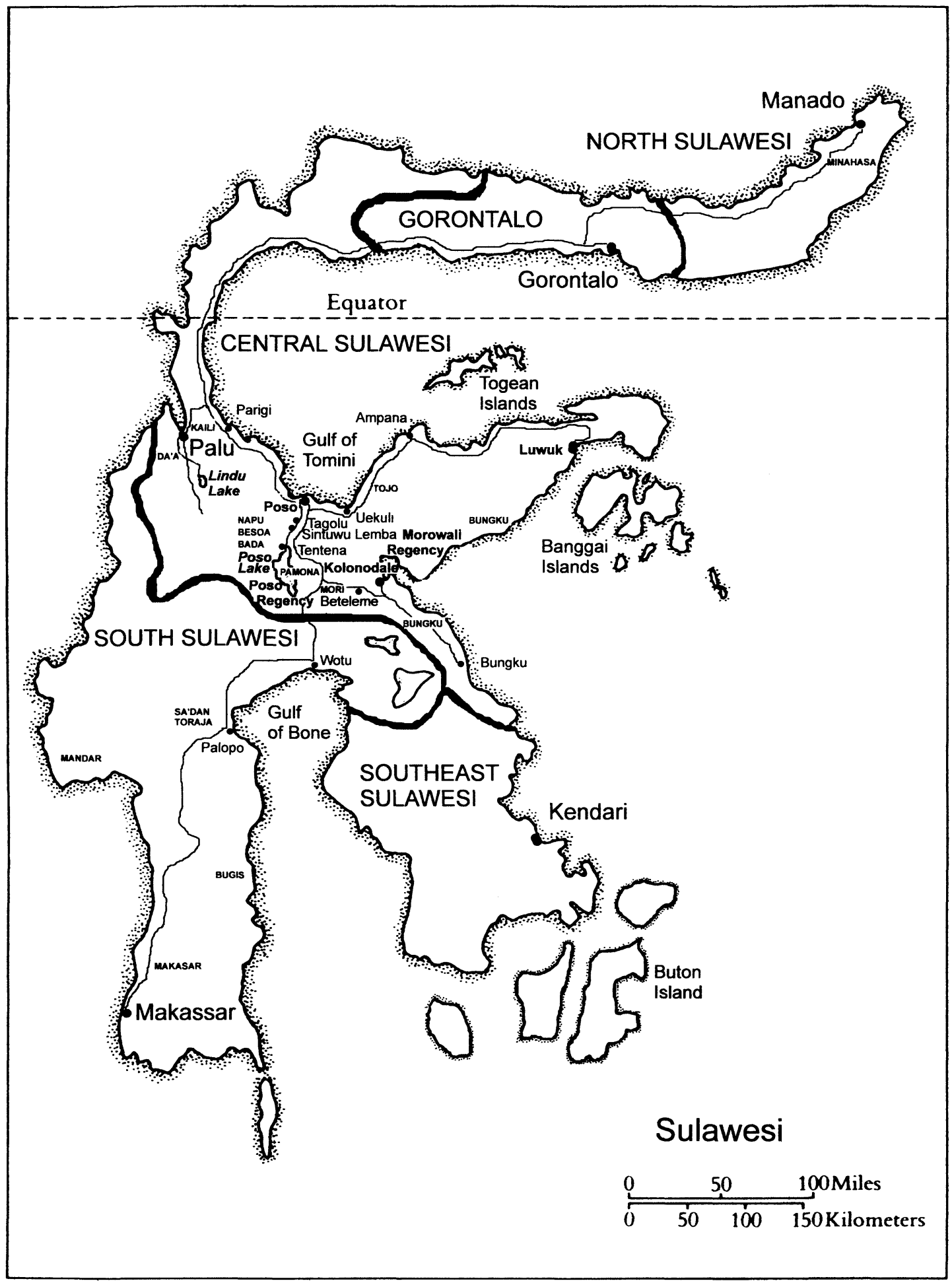

Figure 1. Map of Sulawesi 
Communal violence between Muslims and Protestants began in the eastern Central Sulawesi town of Poso during late December 1998 (Phase One) and recurred in April 2000 (Phase Two). The fighting escalated to civil war conditions throughout the regency (kabupaten) in May 2000 (Phase Three). Beginning in April and continuing to the present (August 2001), arson, vehicle, and neighborhood attacks, as well as masked murders, have rebounded (Phase Four). By the end of what is known as Phase Three (May-July 2000), hundreds of people were seriously injured, from three hundred to eight hundred were killed, and nearly 150 corpses had been burned, decapitated, and dumped into the Poso River or other mass graves. At least 3,500 houses, two schools, and nine places of worship were destroyed in twenty towns. More than seventy thousand persons fled their homes. By July 2000, Poso was virtually empty, referred to as a dead city (kota mati).

The animosity between certain Protestant and Muslim groups in Poso took its particularly violent form under shifting state and military policies. Regency-level political struggles developed in an atmosphere charged with legal turpitude, weak journalism, and incitement by some religious leaders on both sides. As conditions worsened, segments of Poso's Muslim and Protestant communities began to respond to any perceived assault with a pattern of multiplied revenge; not tit for tat, not just explosive anger, but the idea that an extra wallop or calculated punishment was required in the vindictive act. "Our cousin was knifed, so we burn your town. You burned our houses, so we ambush hundreds from your community, kill them, and cut them into pieces." This increasingly calculated retribution pattern gradually became portrayed and justified in vaguely scriptural terms.

Why did such violence between religious communities in Poso suddenly surge only months after the resignation of President Suharto in May 1998? Why did the violence recur and escalate over a period of nearly three years (thus far), remaining unchecked by local and national authorities? And why were Protestants and Muslims who lived only a half day's drive away in western Central Sulawesi still able to remain friendly and communicative, albeit apprehensive, despite the nearby conflicts and a mounting burden of Poso refugees?

Somehow religion interacted with Poso Regency's economic and political structure in a destructive way linked to Indonesia's broader national and international problems. It bears noting, however, that this fight is not about religious doctrines or practices, but about the political economy of being Protestant (or Catholic) and Muslim. Answers to the three questions above reside in the congruence of peculiar Indonesian state conditions and Poso Regency's competing "religious" collectivities, which are based historically on certain types of land and human allegiance claims. Below I first discuss state issues, regional religious history, legal and demographic shifts, and Poso's 1998-1999 regent competition. Then I detail the conflict phases, explore religious rationales, and finally begin to analyze patron-client links that mark a geographic path from the initial urban to the ensuing rural violence. Although the analysis begins with the inextricable context of the state, the intent of this essay is to redirect consideration of Indonesia's political reformation problems so that more attention is focused on the state's interaction with grassroots conditions of outer island regions. It is there where many comparable battles between Indonesia's 
"indigenous" or homeland communities and the migrant or diaspora communities are being fought.

\section{Contemporary State Problems and Ethnonationalist Conflicts}

The 1997 Asian financial crisis had an especially deep impact on Indonesia because of the country's grossly mismanaged banking industry, which worked with the corrupt and nepotistic monopolies set up by the Suharto regime. ${ }^{2}$ Recognition of the Suharto family's role in the economic crisis, along with increasing popular pressure for democratic reforms, led to Suharto's ouster in May 1998. In the following months of former Vice-president B. J. Habibie's presidency, riots characterized as ethnic or religious attacks occurred in Waikabubak, West Sumba; Ketapang, Jakarta; Kupang, West Timor; Makassar, South Sulawesi; and Banyuwangi, East Java; these are just a few of the clashes that immediately preceded Poso's. The December 1998 rioting in Poso, in turn, was overshadowed by even greater violence in Ambon, Maluku that began two weeks later.

During roughly the same time period, Jakarta responded to popular demands for regional autonomy with regional redistricting and laws portending to shift far more control over funds from national and even provincial levels to the regency (kabupaten) level. ${ }^{3}$ As a result of this political transformation, competitions for regency administrative posts now involved higher stakes, and election campaigns became open grounds for communal mobilization in several areas, including Poso. ${ }^{4}$ That the Poso election struggles ultimately coalesced around religious (Protestant, or even Christian, versus Muslim) rather than merely ethnic (Pamona versus Bugis and Javanese) factions, widened the scale of the conflict and signifies the power of twentieth-century transnational influences on the outer islands' economic and religious constellations.

The rapid succession of violent communal conflicts just before and after Suharto's resignation variously suggested top-down models of broad-based conspiracies, or bottom-up models of flawed democratization. According to such models, outbursts of violence in Indonesia either are engineered by national elites stirring up trouble that will require suppression by an authoritarian state, or the outbursts are viewed as the result of liberating democratic reforms (Reformasi) gone awry, descending into lawlessness. In these basic forms, neither model addresses the accumulated resentments and subtle realignments of ethnic, religious, and economic consciousness that have developed over

\footnotetext{
2 See Shalendra D. Sharma, "The Indonesian Financial Crisis: From Banking Crisis to Financial Sector Reforms, 1997-2000," Indonesia 71 (April 2001): 79-110; also, Mark McGillivray and Oliver Morrissey, "Economic and Financial Meltdown in Indonesia: Prospects for Sustained and Equitable Economic and Social Recovery," in Reformasi: Crisis and Change in Indonesia, ed. Arief Budiman, Barbara Hatley, and Damien Kingsbury (Clayton: Monash Asia Institute, 1999), pp. 3-26.

3 These are the 1999 Regional Autonomy Laws (No. 22, 25, 28) passed during Habibie's one-and-a-half year term. See Undang-Undang Otonomi Daerah 1999 (Bandung: Kuraiko Pratama, 1999).

4 On regency election wrangling in Sumba, Central Kalimantan, and Maluku respectively, see Jacqueline Vel, "Tribal Battle in a Remote Island: How District Leaders in Sumba (Eastern Indonesia) Combat the Fading of Their Authority," in this issue; Human Rights Watch, "Indonesia: The Violence in Central Kalimantan (Borneo)," February 28, 2001; Gerry van Klinken, "The Maluku Wars: Bringing Society Back In," Indonesia 71 (April 2001): 1-26, esp. 21.
} 
long periods of time in numerous Indonesian provinces. They also miss the way that precolonial communal ties to land, indigenous hierarchies, and religious separatism in the twentieth century have interacted with contemporary squabbles among elites and their followers for regional power, a scramble fomented by the economic and civic institutional weakness of the post-Suharto state. Finally, these models do not fully appreciate the critical interaction between a fluctuating or otiose state, inclined to solutions based in force, and the opportunistic factionalism that has risen in the statelets of the regional administrations. 5

Dysfunctional postcolonial states as far away as South Asia and sub-Saharan Africa evidence contemporary patterns of ethnoreligious violence that bear more than a passing resemblance to Indonesia's recent disruptions. ${ }^{6}$ In the case of post-Suharto conflict areas such as Central Sulawesi, Maluku, and Kalimantan, recurring structural features include: a history of coastal Muslim kingdoms and Protestant missionization of the interior; New Order (trans)migrant versus indigene economic tensions; the presence of jobless or underemployed youth; heightened provincial and regency battles over elections or redistricting issues; teenage brawls on religious holidays; both rumored and actual attacks on houses of worship; partisan or weakly documented media reports; ineffective or inappropriately involved security troops; and extensive property vandalism, arson, and organized (often masked) murder campaigns. Both the preexisting social conditions and the conflict features follow these repeating patterns.

Many observers of the Poso case, within and beyond Indonesia, thus have suspected the handiwork of political provocateurs, at the national, or even international level. In several other Indonesian cases, abundant evidence exists that paid henchmen (preman) planted rumors or committed criminal acts to incite communal fear and revenge. ${ }^{7}$ In Poso, it appears that certain district politicians helped incite violence and, as conflicts unfolded, some provincial religious leaders supported the attackers. Moreover, one of the three Christians tried and convicted for Muslim butchery in Poso's Third Phase was an immigrant ex-convict of likely preman status. Yet despite the myriad rumors and media allegations, there is no firm evidence for active involvement from Jakarta. As Gerry van Klinken notes well for the Maluku case, the central state's role was more likely characterized by impotence, or was at best a matter of periodic and opportunistic collusion, rather than strategic planning and investment. ${ }^{8}$ Indonesia's army and police forces were undergoing major crises and

\footnotetext{
${ }^{5}$ A good case study of these interactive processes is Geoffrey Robinson, The Dark Side of Paradise: Political Violence in Bali (Ithaca: Cornell University Press, 1995).

6 Van Klinken's lucid analysis of the Maluku conflicts proposes global comparisons with Africa's failed states; van Klinken, "The Maluku Wars." On recurring features of postcolonial conflicts, see Stanley J. Tambiah, Leveling Crowds: Ethnonationalist Conflicts and Collective Violence in South Asia (Berkeley: University of California Press, 1996).

7 Joshua Barker, "State of Fear: Controlling the Criminal Contagion in Suharto's New Order," Indonesia 66 (October 1998): 7-42; Robert W. Hefner, Civil Islam: Muslims and Democratization in Indonesia (Princeton: Princeton University Press, 2000); Loren Ryter, "Pemuda Pancasila: The Last Loyalist Free Men of Suharto's Order?," Indonesia 66 (October 1998): 45-73; James T. Siegel, A New Criminal Type in Jakarta: Counter-revolution Today (Chapel Hill: Duke University Press, 1998).

8 Van Klinken, "The Maluku Wars," pp. 7-10.
} 
restructuring during this period. ${ }^{9}$ And in Poso, like Maluku, there were numerous eyewitness reports of non-neutral participation by, and tensions between, the army and police divisions. Therefore, in the current absence of evidence of direct state mischief, I argue that the state's clearest role in the Poso conflicts concerns how its shifting and irresponsible policies fomented the destructive factionalism of regional elites and their client groups.

Additionally, Poso's political problems, like those of Maluku and Kalimantan, were exacerbated by inflammatory mass media reports, which led Indonesians in other areas to see distant local disputes as pan-Indonesian religious or ethnic crises. ${ }^{10}$ The city of Poso had no local newspapers or television stations, so almost all reporting was conducted by outside journalists, the nearest originating in Palu. Many of the reporters assigned to the conflict were unwilling or unable to enter the war-torn area, and the resulting journalism was minimal or one-sided at best. ${ }^{11}$ Most insidious for local readers and frustrating for scholars were the continuing brief reports of violent events that only hinted at the personal, religious, or geographic identities of "culprits" and "victims" in a simultaneously vague and incendiary fashion. Such reporting left readers with virtually no solid data about the conflicts' early chronology or causes, while tacitly encouraging Indonesian readers to view themselves as potential or actual victims of generally unnamed religious enemies.

\section{Colonial and Regional Religious History}

Poso, like the provincial capital of Palu, is an old coastal port that links sea trade via riverine routes-and now roads-to the agricultural valleys and daunting mountain ranges that blanket interior Sulawesi. Muslim traders, often Bugis and Arabs, frequented and settled in such ports prior to the Dutch colonial domination of the region that began in the late 1800 s. Seafaring Muslims influenced and married indigenous, coastal people, most of whom eventually adopted Islam. By contrast, the scores of small interior populations, which vary gradually by language and cultural practices in a mosaic pattern, generally remained apart from state formations and did not convert to Islam or any other world religion prior to Dutch penetration. ${ }^{12}$ These highlanders, who subsisted by shifting cultivation of rice, tree crops, and tubers, thus

9 The Editors, "Changes in the Civil-Military Relations Since the Fall of Suharto," Indonesia 70 (October 2000): 125-138; The Editors, "Current Data on the Indonesian Military Elite: January 1, 1999-January 31, 2001," Indonesia 71 (April 2001): 135-173.

${ }^{10}$ On comparable mass media provocations in India, see Paul R. Brass, Theft of an Idol: Text and Context in the Representation of Collective Violence (Princeton: Princeton University Press, 1997); and Tambiah, Leveling Crowds.

11 See Jake Lynch and Annabel McGoldrick, "Peace Journalism in Poso," Inside Indonesia (April-June 2001): 24-25; and Kathleen Reen, J. Lance Alloway, Oren A. Murphy, and Yon Thayrun, "Crisis in Poso," unpublished report prepared by Internews Indonesia, June 28, 2000.

12 For an overview of Central Sulawesi languages and dialects, see chapters IV-VII in J. Noorduyn, $A$ Critical Survey of Studies on the Languages of Sulawesi (Leiden: KITLV Press, 1991). 
became targets of Dutch Protestant missionization, which intensified after 1905 under the Ethical policy. ${ }^{13}$

The indigenous religion of Central Sulawesi highlanders was inseparable from the land cleared by their ancestors. Moreover, highland populations traditionally traced their group identity - the foundation of what became, under state pluralism, "ethnicity" - on their place of origin. Thus the sacral aspect of situationally defined, insider versus outsider or "ethnic" disputes over land runs very deep, although it is important to note that precolonial vendetta violence and "tribal" warfare did not strictly follow highland versus lowland divisions before Dutch interference. During the colonial period, however, the relatively small and fragmented highland groups became increasingly aware of their minority status on the island compared to more numerous lowlanders, such as Bugis or Makasar people. They also became aware of their insignificance in the colony, and later the nation, compared to the Javanese. Only the Protestantism introduced by European missionaries proposed to unite highland settlements into larger confederations forged through church affiliation and even to ally them to powerful communities far beyond the borders of their ancestral gardens and surrounding rainforests.

A. C. Kruyt opened the earliest and largest mission in Central Sulawesi for the Netherlands Mission Society (Nederlands Zendeling Genootschap). The headquarters was established in Tentena to proselytize the animists living around Poso Lake. In this region, now encompassed by the Poso Regency, indigenous communities became united through their colonial experience and began to identify themselves as Pamona (To Pamona, literally "those from/of Pamona"). They are almost uniformly members of the Central Sulawesi Protestant Church (Gereja Kristen Sulawesi Tengah, or GKST) descended from Kruyt's mission. ${ }^{14}$

In the western highlands south of Palu, by contrast, Protestant missions arrived several decades later when the colonial government gave religious jurisdiction over that region to the Salvation Army based in England. These two European Protestant missions approached their congregations differently in several respects. Of particular importance here was the Salvation Army's adoption of the Malay (now, Indonesian) language and a uniform, national administration of doctrines and practices, which contrasted with Kruyt's use of regional languages and his focus on the Christianization of very localized ancestral customs (adat). This latter approach intensified the

\footnotetext{
${ }^{13}$ On the indigenous religion and missionization of western and eastern Central Sulawesi areas respectively, see Lorraine V. Aragon, Fields of the Lord: Animism, Christian Minorities, and State Development in Indonesia (Honolulu: University of Hawai'i Press, 2000); and Albert Schrauwers, Colonial 'Reformation' in the Highlands of Central Sulawesi, Indonesia, 1892-1995 (Toronto: University of Toronto Press, 2000).

14 Groups who now call themselves Pamona were named "the Bare'e-speaking Toradja" by Adriani and Kruyt. See Nicolaus Adriani and Albertus C. Kruyt, De Bare'e-Sprekende Toradja's van Midden Celebes, 3 vols, 2nd ed. (Amsterdam: N. V. Noord-Hollandsche Uitgevers Maatschappij, 1950); Joost Cote, "Colonising Central Sulawesi: The 'Ethical Policy' and Imperialist Expansion, 1890-1910," Itinerario 20,3 (1996): 87108; Schrauwers, Colonial 'Reformation.'
} 
development of a religiously based "regional nationalism" among Pamona Protestants during the twentieth century. ${ }^{15}$

In both the western (Palu) and eastern (Poso) areas of Central Sulawesi, the Dutch administration sought to enlist the newly missionized highlanders as colonial auxiliaries which it hoped would act, collectively, as a Protestant buffer against the potential political threat of Islam based at the coasts. The Dutch introduced regulations and trade initiatives that disrupted precolonial highland-lowland alliances entailing produce exchanges, military support, and "royal" or elite marriages between coastal Muslim kingdoms and tributary highland centers. ${ }^{16}$ Dutch administrators also worked to curtail the annual population movements linked to highland swidden farming and to centralize the scattered settlements into larger "model" villages.

In the eastern area by Poso Lake, the Dutch were particularly aggressive in pressuring the Pamona to abandon swidden rice farming in favor of wet-rice agriculture, which they considered more "scientific," productive, and less tied to the old "pagan" religion. Protestant missions opened schools and clinics for the new highland converts, further isolating them socially from the Muslim coastal populations and providing them with distinctive government treatment or "privileges." Educated Protestant converts from the highlands were given local bureaucratic positions, including assignments as teachers for new schools in remote areas. By the time the Japanese invaded and occupied Sulawesi during World War II, most highlanders were more closely linked, both economically and socially, to the Protestant missions and the Dutch colonial regime than they were to coastal Muslims and urban independence movements.

After independence was declared by Sukarno in 1945, Sulawesi highlanders suffered further from their strategic location between the Muslim-majority peninsula of southwestern Sulawesi and the Protestant-majority peninsula of northern Sulawesi, both centers of secessionist movements during the late 1950s and early 1960s. Villagers now describe the confusing and violent overflow of these two movements-Permesta in North Sulawesi and the Kahar Muzakkar or Darul Islam rebellion in South Sulawesias the time of "gangs" (gerombolan).

In South Sulawesi, the Japanese occupation and surrender was followed by a mutual distrust between highland Protestant Sa'dan Toraja and lowland Muslim Bugis factions, even those with seemingly common nationalist goals. ${ }^{17}$ Moreover, many lowland Muslims who fought for national independence were angered by the continuity of aristocratic privilege in the Java-centric Republic. A Bugis businessman and former

\footnotetext{
15 On the concept of "regional nationalism" in Sulawesi, see David E. F. Henley, Nationalism and Regionalism in a Colonial Context: Minahasa in the Dutch East Indies (Leiden: KITLV Press, 1996); also, Schrauwers, Colonial 'Reformation,' pp. 77-88.

16 Items traded from the coasts included sea salt, woven cloth, and bronze trays. Items traded from the highlands included gold flakes, dammar resin, rattan, barkcloth, and slaves-although, given significant differences in demography and land use, the slave trade from Central Sulawesi was minimal compared to that described by Bigalke for South Sulawesi. Terence W. Bigalke, "A Social History of 'Tana Toraja' 1870-1965" (PhD dissertation, University of Wisconsin at Madison, 1981), chap. 2; Lorraine V. Aragon, "Twisting the Gift: Translating Precolonial into Colonial Exchanges in Central Sulawesi, Indonesia," American Ethnologist 23,1 (1996): 43-60; and Aragon, Fields of the Lord, chapters 3-4.

17 Bigalke, "A Social History," chapter 10.
} 
Muhammadiyah teacher named Kahar Muzakkar who fought in Java during the 1945 revolution was sent by Sukarno's military to persuade disgruntled South Sulawesi secessionists to join the Indonesian Republic. He ended up joining and leading the rebels instead. In 1953, after he was denied the military command post he demanded, Muzakkar allied with the Darul Islam movement from West Java. His aim was to install on Sulawesi an Islamic Republic opposed to the "feudalism" of the regional nobility, ancestral forms of worship, and Dutch influences such as Protestantism. ${ }^{18}$

Armed Darul Islam rebels from South Sulawesi moved north through the mountains into Central Sulawesi to attack animist and Protestant villages. Highlanders fought back with the weapons at hand: machetes, spears, blowpipes, and headhunting displays. Hundreds, perhaps thousands, of villagers were tortured, killed, or forced to flee for their lives and resettle in new areas. Thus the incoming Protestant Permesta militias from the Minahasa region of North Sulawesi sometimes were welcomed and supported by highland Protestant villages as allies against Muslim attackers from South Sulawesi. In the Poso Lake region, however, Permesta forces mistreated locals, which led to the creation of a Pamona defensive militia called the Youth Movement of Central Sulawesi (Gerakan Pemuda Sulawesi Tengah, GPST). ${ }^{19}$ This organization would disband after Permesta only to be recreated during the 1998 Poso violence.

The Permesta rebellion from North Sulawesi, which joined briefly with Muzakkar's Muslim forces, ultimately was resolved as an internal army affair in 1961. The Muslim rebellion from South Sulawesi, however, continued until Muzakkar was shot by Republican forces in February 1965. Throughout the two decades of regional chaos, local Protestant churches, which had gained de facto independence during World War II, became the major force of stability and civic organization in the highlands, running Sunday services, schools, and clinics in difficult, war-torn circumstances. By contrast, most Protestant highlanders experienced the Minahasan and Bugis-led secessionist rebels, as well as the Japanese, returning Dutch, and Javanese-led Republican forces as threats rather than solutions to their security, subsistence patterns, and local autonomy.

The ensuing Suharto regime was a period when highlanders, like most Indonesians, acceded to many new regulations over their individual and collective rights in return for relatively greater stability and prosperity. Indonesians were required to follow one of five government authorized religions: Islam, Protestantism, Catholicism, Hinduism, or Buddhism. Whereas the Protestant population in the nation was only about 6 percent, the Protestant population of Central Sulawesi was nearly 20 percent, spread throughout most of the interior land as well as the mission-influenced town of Poso. The more dense coastal settlements still gave Muslims a provincial majority of 76

\footnotetext{
18 See Barbara S. Harvey, "Tradition, Islam, and Rebellion: South Sulawesi 1950-1965" (PhD dissertation, Cornell University, 1974); Barbara S. Harvey, Permesta: Half a Rebellion (Ithaca: Cornell Modern Indonesia Project, Southeast Asia Program, 1977); and Audrey R. and George McT. Kahin, Subversion as Foreign Policy: The Secret Eisenhower and Dulles Debacle in Indonesia (New York: The New Press, 1995). See also, Bigalke, "A Social History," chapter 11; Gregory L. Acciaioli, "Searching for Good Fortune: The Making of a Bugis Shore Community at Lake Lindu, Central Sulawesi" (PhD dissertation, Australian National University, 1989); and Thomas Gibson, "Islam and the Spirit Cults in New Order Indonesia: Global Flows vs. Local Knowledge," Indonesia 69 (April 2000): 41-70.

19 Schrauwers, Colonial 'Reformation,' pp. 82-84.
} 
percent, but that was significantly less than the roughly 87 percent majority they held in the Indonesian population as a whole during the 1980 s. Catholics, already a tiny 3 percent minority in the nation made up a negligible .3 percent in the province. ${ }^{20}$ During most of the Suharto regime, the Central Sulawesi highlands were solidly Protestant and Protestants engaged in a modicum of power sharing, at the district (kecamatan), and sometimes even regency (kabupaten), level, with the more numerous Muslims who dwelled on smaller, urban areas at the coasts. The Protestant domination of civil service positions under the Dutch gradually was modified by influence from the national Muslim majority.

Despite their overwhelming national majority, however, Indonesian Muslims often saw their organizations repressed by the early Suharto regime in which Catholic intelligence personnel and military commanders such as Benny Murdani played a major role. Continuing the Dutch colonial policy on Islam developed by Snouck Hurgronje, the early Suharto regime patronized Muslim ritual and charitable activities while neutralizing its threat as a potential political challenge. This policy shifted dramatically in the last decade of Suharto's rule with the creation of new institutions such as the Indonesian Muslim Intellectuals Association (ICMI). Chaired by VicePresident Habibie, the organization sought to patronize modernist Muslims as economic development agents-making an implicit distinction between these Muslims and ethnic Chinese, who usually are Christians. ${ }^{21}$

Even as early as 1978, Muslim demands led Protestant proselytizing and mission funding to be more closely controlled by the Suharto government, and many Central Sulawesi clinics and schools that had been funded and operated by Protestant churches were seized by the government. ${ }^{22}$ The Suharto regime increasingly installed modernist Muslims in high military posts, supported Islamic banking, intensified Islamic studies in the school curriculum, and funded more Islamic schools and buildings. President Suharto even performed the pilgrimage to Mecca in 1991. Although such pro-Muslim acts and signals issued at the highest levels of government developed in concert with, rather than simply created, popular trends such as Islamic ritual reform, veiling by women, and Muslim banking, the cumulative impact was a distinct national shift favoring Islam. ${ }^{23}$

${ }^{20}$ The Suharto government stopped releasing census figures on the nation's religious composition in the late 1980s, presumably for fear of reactions to a Muslim decline. See Rita Smith Kipp, Dissociated Identities: Ethnicity, Religion, and Class in an Indonesian Society (Ann Arbor: University of Michigan Press, 1993), p. 101. The percentages here are drawn from Statistik Indonesia 1986 (Jakarta: Biro Pusat Statistik, 1987), pp. 168-169; and, Indonesia 1992: An Official Handbook (Jakarta: Department of Information, 1992), pp. 55-72.

21 Robert W. Hefner, "Islam, State, and Civil Society: ICMI and the Struggle for the Indonesian Middle Class," Indonesia 56 (1993): 1-37. On the distinctive colonial experience of, and resentment against, ethnic Chinese, see The Role of the Indonesian Chinese in Shaping Modern Indonesian Life, special issue of Indonesia (Ithaca: Cornell Southeast Asian Program, 1991); and James T. Siegel, Solo in the New Order: Language and Hierarchy in an Indonesian City (Princeton: Princeton University Press, 1986), chapter 9.

${ }^{22}$ Hyung-Jun Kim, "The Changing Interpretation of Religious Freedom in Indonesia," Journal of Southeast Asian Studies 29,2 (1998): 357-373; Aragon, Fields of the Lord, p. 304.

23 John R. Bowen, Muslims through Discourse (Princeton: Princeton University Press, 1993); Suzanne A. Brenner, "Reconstructing Self and Society: Javanese Muslim Women and 'the Veil,'" American Ethnologist 23,4 (1996): 673-697; Hefner, "Islam, State, and Civil Society"; Hefner, Civil Islam; and Robert W. Hefner, 
The policy changes promoted entrenchment on both sides. They enhanced citizens' perceptions of past economic and political discrimination towards Muslims, and present and future discrimination towards Christians. In Central Sulawesi, Muslim and Protestant groups competed to present themselves as favored, even "blessed," vehicles for economic development, often using funds sent from Jakarta or overseas. These contests attracted attention as well as indignation in urban areas with the construction of increasingly more ostentatious churches and mosques, buildings that became targeted symbols of undeserved wealth and enmity during the communal conflicts in Poso and elsewhere.

\section{Postindependence Legal, Demographic, and Economic Shifts}

Between the 1960s and the 1990s, Indonesian legislation decreased traditional land and political rights in service of national goals. ${ }^{24}$ The 1960 Basic Agrarian Law ceded legal control of customarily held village land (tanah adat) to the state for potential development purposes. New forestry and investment laws in 1967 allowed foreign companies to finance and control industries in forested interior areas. Suharto's 1973 Presidential Decree No. 2 designated Central Sulawesi and nine other outer island provinces as new transmigration sites, where the aim became less to relieve population problems on Java than to stimulate more profitable outer island agriculture and "national development." 25 The 1974 Regional Government Law and the 1979 Village Government Law then removed power from customary councils of elders and placed it in the hands of the national civil service bureaucracy, increasing political control by outsiders. ${ }^{26}$

In eastern Central Sulawesi, both voluntary migration from South Sulawesi and government-sponsored transmigration programs for Javanese and Balinese, which began as early as the 1950s, augmented mainly the Muslim and Hindu populations. ${ }^{27}$ With the new roads and development projects initiated during the Suharto regime, Poso grew from a tiny fishing port and farming town to a bustling regency capital. The ambitiously named Trans-Sulawesi Highway was built along the coasts wherever possible, but transected the mountainous interior directly south of Poso via Tentena en route to South Sulawesi.

\footnotetext{
"Markets and Justice for Muslim Indonesians," in Market Cultures: Society and Morality in the New Asian Capitalisms, ed. Robert W. Hefner (Boulder: Westview Press, 1998), pp. 224-259.

24 Michael R. Dove, "The Agroecological Mythology of the Javanese and the Political Economy of Indonesia," Indonesia 39 (1985): 1-36; Colin MacAndrews, Land Policy in Modern Indonesia (Boston: Oelgeschlager, Gunn \& Hain, 1986); Nancy Lee Peluso, Rich Forests, Poor People (Berkeley: University of California Press, 1992).

25 Timothy Babcock, "Transmigration: The Regional Impact of a Miracle Cure," in Central Government and Local Development in Indonesia, ed. Colin MacAndrews (Singapore: Oxford University Press, 1986), pp. 157-189.

26 Tsuyoshi Kato, "Different Fields, Similar Locusts: Adat Communities and the Village Law of 1979 in Indonesia," Indonesia 47 (1989): 89-114.

27 A segment of the early Balinese transmigrants were Protestant converts no longer welcome in Hindu Bali. See Gloria Davis, "Parigi: A Social History of the Balinese Movement to Central Sulawesi, 1907-1974" (PhD dissertation, Stanford University, 1976).
} 
56 Lorraine V. Aragon

As forests still covered well over half of the province's surface through the 1980s, New Order development in Central Sulawesi focused on timber industries. High-value hardwoods such as ebony, which grow in the forests around Poso Lake, were targeted because of the mountainous terrain and limited interior roadways. News reports periodically noted that ebony, worth thousands of US dollars per cubic meter, was being cut illegally and smuggled by truck from Poso via Palu's shipping ports to evade government controls and taxation. ${ }^{28} \mathrm{Few}$ indigenous Pamona were direct economic beneficiaries of this extractive industry, which tended to employ Muslim immigrants.

Family-based farming of cash crops also generated new wealth, but again mostly for ambitious Muslim migrants and urban merchants, including Chinese ones. Although Pamona and other highland Protestants did grow some cash crops such as cloves, coffee, and cacao, highlanders remained primarily subsistence rice farmers. Few became involved in market activities beyond the sale of small crop surpluses in exchange for basic supplies or cash needs. While Muslim Bugis or Makasar migrants became middleman traders or worked for private businesses through their patronclient networks, Protestant highlanders traditionally had no capitalist business experience and much more localized exchange networks. ${ }^{29}$ Many ran up high-interest debts to immigrant salespeople, whose kiosks offered credit, and so found their next season's produce already owed before harvest.

Highlanders traditionally left their ancestral villages only for higher education, church employment, or civil service jobs, if they could obtain them. As non-Pamona bought up or were allotted lands through transmigration programs, many Pamona youths found themselves landless as well as jobless by the end of the Suharto regime. Opportunities for social mobility depended upon personal connections to members of the regional bureaucracy. Indigenous groups' access to positions remained available mainly to descendants of the precolonial nobility, and Protestants' ties to recognized aristocracies were fewer than those of Muslims. Although a small percentage of Protestant Pamona leaders did increase their economic standing dramatically during the New Order, the mass of Pamona and other highland Protestant farmers did not.

After the financial crisis of 1997, even more voluntary migrants entered the Poso Regency from South Sulawesi, and many purchased land to raise cacao. Cacao had become the "hot" export crop, as its sale price in rupiah, which was pegged to the US dollar, continued to rise while the fixed rupiah value of salaries and many other local products fell due to inflation. Informal reports note that Bugis migrants angered Pamona and other indigenous Protestant groups by entering "their" ancestral forests with chainsaws to clear fields for cacao and other cash crop plantations. Whereas Muslims claimed that Muslim immigrants worked harder than the indigenous peoples, Protestant residents saw their declining relative population and economic status as engineered by the increasingly Muslim government officials who benefited most from the commercial industries and plantations favored by Jakarta. In contrast to many areas of western Central Sulawesi, the Poso Regency began to lose its earlier

\footnotetext{
28 "Illegal Ebony Tree Cutters Get Minister's Warning," Jakarta Post, November 24, 1990.

29 On Bugis strategies of migration and trade dominance, see Acciaioli, "Searching for Good Fortune," and Gregory Acciaioli, "Kinship and Debt: The Social Organization of Bugis Migration and Fish Marketing at Lake Lindu, Central Sulawesi," in Authority and Enterprise among the Peoples of South Sulawesi, ed. Roger Tol, Kees van Dijk, and Greg Acciaioli (Leiden: KITLV Press, 2000), pp. 211-239.
} 
demographic balance and exchange relationship between a Muslim-dominated lowlands and a Protestant-dominated highlands.

Although refugees from Poso, as well as less affected provincial observers, uniformly described their surprise and shock at the ethnoreligious violence beginning in 1998, there were earlier signs of trouble. The 1998-2000 fighting in Poso echoed comparable market fights, nighttime attacks, and religious threats that occurred and were repressed militarily in both Palu and Poso during the decade before Suharto resigned. ${ }^{30}$ Additional communal conflicts occurred at both transmigration and voluntary migration sites in Central Sulawesi, which became arenas for small-scale ethnic disputes over land rights. ${ }^{31}$ Although most of the problems were between locals and immigrants of different religions (particularly Protestants and Muslims), some conflicts between Poso Regency indigenes and South Sulawesi migrants took place in the Bungku area where both groups were Muslim. ${ }^{32}$ Such data indicate that insideroutsider friction over the economic use of land, rather than religious strife per se, was the basal line of fracture. Immigrants in Central Sulawesi, formerly few in number, were expected to defer to elders and to the customary practices (adat) of the original landclearing group. These expectations increasingly were not met in the New Order when migrants began to view themselves as national citizens equally entitled to resource appropriation as longtime residents. ${ }^{33}$ In Poso Regency, the apparently uniform yet unequally beneficial regulations of the New Order only exacerbated the Protestant Pamonas' regional nationalism.

As the town of Poso grew during the Suharto regime, it became increasingly diverse ethnically. Protestants besides Pamona included Minahasans, Balinese, and Chinese as well as Mori, Napu, Besoa, and Bada' people from within the regency. Muslims included Arabs, Javanese, Bugis, Makasar, Mandar, Buton, and Kaili people as well as Tojo, Togian (Togean), and Bungku people from the regency. ${ }^{34}$ The small Catholic minority was comprised of Minahasans and Chinese, as well as migrants from former Portuguese colonies such as Flores. Balinese were the only Hindus. Overall, by the late 1990s, the Muslim percentage of the Poso city population exceeded 50 percent, and Muslim Bugis gained control of much urban commerce. Simultaneously, according to reports, competition increased between Muslim Bugis and Christian Chinese business people applying to receive development contracts through the regent's office. Given Indonesian patron-client relations that follow communal lines, it became clear that the selection of the next Poso regent would largely determine which ethnic or religious

\footnotetext{
${ }^{30} \mathrm{~A}$ few of these events are described in Aragon, Fields of the Lord, pp. 316-317; Lorraine V. Aragon, "Can Central Sulawesi Christians and Muslims Get Along?" Antropologi Indonesia 24,63 (2000): 59-64;

Schrauwers, Colonial 'Reformation,' pp. 91-92, 226-227.

31 See Greg Acciaioli, "Placing Claims to Land: The Grounds of Religious and Ethnic Conflict at Lake Lindu, Central Sulawesi," in this volume, and Aragon, Fields of the Lord, pp. 303-304.

32 Kie-Eng Go, "Political Agenda behind the Riot of Poso," presented in the Briefing on the Current Human Rights Issues in Indonesia with the US Congressional Human Rights Caucus, February 9, 1999.

33 Acciaioli, "Placing Claims to Land"; Aragon, Fields of the Lord, pp. 303-304.

34 Throughout this text, Makasar designates the ethnic group of South Sulawesi origin, whereas Makassar (with a double " $s$ ") is the new, official name of the provincial capital of South Sulawesi, which was called Ujung Pandang during the Suharto regime. Togean also is a new spelling of Togian that is gaining currency and geopolitical import.
} 
58

Lorraine V. Aragon

groups would have the most political and economic support from the next regency administration.

\section{The 1998-1999 Regent Contest and Political Context}

Sulawesi was a single administrative unit with its capital in the southern, Muslimmajority city of Makassar (formerly Ujung Pandang) before the separate Christianmajority province of North Sulawesi was created in 1957 under pressure from Permesta leaders. Central Sulawesi later was separated from North Sulawesi in 1964 following similar demands for regional autonomy. Pressed by further appeals in late 1999 (between Poso's first and second conflict phases described below), President Habibie created a wealth of new regencies and provinces, including several in Sulawesi. These show some signs of religious redistricting or even gerrymandering. A new, mainly Muslim, regency of Morowali (including a small Protestant Mori minority within a larger, Muslim Bungku majority) was split off from the Protestant-majority Poso Regency, which had been territorially stable during the New Order. Additionally, a new Muslim-majority province of Gorontalo was separated from the southern area of Protestant-majority North Sulawesi. Thus, Central Sulawesi became located between two other Muslim-majority provinces, and more Muslim-majority regencies were created, leaving Poso Regency, with its anomalous Protestant population, smaller and more isolated.

During the Suharto regime, regents (bupati) were elected by the Regional People's Representative Council (Dewan Perwakilan Rakyat Daerah Tingkat Dua, or DPRD II) in consultation with the governor who, when an agreement had been reached, forwarded the nomination to the Minister of the Interior (Menteri dalam Negeri, or Mendagri). ${ }^{35}$ When the Poso conflicts began in late 1998, Habibie had replaced Suharto, and the Central Sulawesi governor was a Muslim retired army officer named H. B. Paliudju from the Da'a Kaili ethnic group originating in the mountains west of Palu. ${ }^{36}$ Most Da'a are Salvation Army Protestants. Beyond his military connections, one of Paliudju's strengths as governor likely was that he could appeal on religious grounds to the province's Muslim majority and yet appeal on ethnic grounds to the area's indigenous groups, including Protestant highlanders. Paliudju, however, lost support from Jakarta after the 1999 elections, probably because he had opposed Megawati's leadership of PDIP (Partai Demokrasi Indonesia-Perjuangan, the Indonesian Democratic Party of Struggle). Paliudju was replaced in February 2001 by Aminuddin Ponulele, former rector of Tadulako University in Palu and a member of a prominent Muslim, coastal Kaili family. Ponulele was supported by Golkar, which won

\footnotetext{
35 On the complexities, past manipulation, and present confusion in regency elections, see Michael Malley, "Regions: Centralization and Resistance," in Indonesia Beyond Suharto, ed. Donald K. Emmerson (Armonk, NY: M. E. Sharpe, 1999), pp. 71-105; and Reen et al., "Crisis in Poso."

36 Reportedly there was an upset in 1995 when the Minister of the Interior, Moch Yogie SM, and a DPR Golkar leader named Harmoko advanced Paliudju over several other leading Muslim contenders for governor. See "Soal Balon Gubernor Sulteng FKPPI Sulteng Ajukan Tiga Jendral," Republika, November 3, 1995.
} 
twenty-one of forty-five seats in the DPRD, and by PDIP, which came in second in the elections. ${ }^{37}$

Habibie, although of mixed Javanese and Arab descent, was born and raised in South Sulawesi, which gave him native son (anak daerah) support in that province, as well as from modernist Muslims more generally. Even in the 1999 elections, as Golkar's vote plummeted nationally, Golkar still received roughly 37-85 percent of votes in the individual Poso Regency districts (kecamatan), and almost 55 percent overall in Central Sulawesi, compared to only 26 percent nationwide. ${ }^{38}$ Golkar's support in some districts of Poso Regency and throughout the province, however, may have had less to do with Habibie's personal appeal than to the inertia of the past status quo. Central Sulawesi villagers long had been pressured by New Order officials to vote only Golkar, and many no doubt desired to stay on the good side of the government in power, with its promises of village development funds.

When the Poso violence began in December 1998, the incumbent Poso regent was a Golkar-backed Muslim named Arief Patanga whose term was due to expire in June 1999. Arief Patanga's ethnicity was unknown or unclear (nggak jelas) to most Indonesians or foreigners I questioned, but an Indonesian NGO worker identified his heritage as Tojo, a precolonial, Bugis-influenced, Muslim kingdom and now district (kecamatan) centered east of Poso and west of Ampana. ${ }^{39}$ A Pamona Protestant candidate named Yahya Patiro sought the regent opening with the support of many Protestants in the district. Patiro was second in command to Patanga as regional secretary (secretaris wilayah daerah, or sekwilda), an example of the kind of MuslimProtestant power split that had been brokered in prior decades. Patiro was championed by Herman Parimo, a Pamona member of the Regional People's Representative Council (DPRD II) who also had widespread Protestant support. Patiro's main competitor was a PPP-supported (PPP, Partai Persatuan Pembangunan, the Unity Development Party) Muslim candidate named Damsyik Ladjalani, whose family was from the Togian Islands, just north of Poso. The Togian Islands are a midpoint linking Bugis-dominated trade between Gorontalo to the north and Ampana to the south. There was also another Muslim candidate seeking Golkar support named Abdul Muin Pusadan. Originating from the distant Bungku area, Pusadan was originally considered to be an underdog, unlikely to win. Pusadan did triumph, however, after the reputations of all the other major candidates were impugned during the Poso conflicts.

\section{The Conflict Phases}

Presenting the chronology of a communal conflict entails inevitable problems in sequencing as well as in selecting which fragments to include. ${ }^{40}$ Recounting the Poso

\footnotetext{
37 Ahmad Setiawan, "Jabatan Diharap, Restu Digarap," Detak No. 122, November 27, 2000.

38 I am indebted to Kevin Evans for data on Central Sulawesi and Poso Regency voting outcomes by party.

39 The Tojo "kingdom" is described briefly in Adriani and Kruyt, De Bare'e Toradja's, vol. 1, and in Jane M. Atkinson, The Art and Politics of Wana Shamanship (Berkeley: University of California Press, 1989).

40 Veena Das, "Specificities: Official Narratives, Rumor, and the Social Production of Hate," Social Identities 4,1 (1998): 109-130, p. 110; Tambiah, Leveling Crowds, pp. 317-320.
} 
conflicts is especially problematic. I did not reach the Poso Regency during the active conflict period and, understandably, both Christian and Muslim refugees I interviewed elsewhere presented one-sided narratives characterized by extreme passion and limited scope. As my earlier fieldwork was based primarily in the highlands, I have slightly greater knowledge of Protestants' historical and contemporary interests. Nevertheless, I also have Muslim friends in the province, and my sympathies lie with all individuals and communities injured by these events.

I rely, then, on much layering of my own inquiries with others' documents, especially journalism and NGO reports. Yet, most journalism about the Poso violence has been stilted and less than thorough for several reasons. The major news publications had their attention focused on more glaring problems in Java, Aceh, East Timor, Irian (West Papua), and Maluku, to name just a few. Sulawesi journalists not only had little training in the responsible coverage of communal conflicts, they too were enmeshed in familiar Indonesian financial problems. Many could not afford carfare to Poso or long-distance telephone calls, so they relied on the reports of newly arriving refugees and inflammatory rumors. Dependence on refugees' reports undoubtedly amplified the coverage of Christians' experiences of Phases One and Two, and Muslims' experiences of Phase Three. Reporters generally also were cautious in their approach and in their portrayals of government officials, since they too, like so many others, were subject to the sway of money-filled envelopes (amplop or empelop). Therefore, the chronology below must be considered preliminary. The sequencing separates what observers since the second incident in April 2000 have called the conflict "phases" (fase) or "chapters" (jilid or bab). Phases One and Two are clearly separated in time by over a year, while Two and Three are separated by only a few weeks and are clearly related. Phase Four is somewhat less well defined because it is still ongoing.

\section{Phase One}

Reports agree that violence in the city of Poso began with a quarrel between two drunken youths on December 24, 1998, the eve of both Christmas and Ramadan. A young reveler from the Protestant Lombogia neighborhood ended up knifing the hand of a youth from the Muslim Kayamanya neighborhood. The residents of Kayamanya, situated just west of the Poso River, generally were of Bugis descent, with many originating from Wotu, a South Sulawesi village in the Gulf of Bone, where the dialect shows similarities with Bugis, Pamona, Buton, and Kaili languages. ${ }^{41}$ Many Kayamanya residents were affiliated with local Al-Khaira'at organizations, although few had received advanced formal education. ${ }^{42}$ By contrast, most residents of Lombogia, located across the river, were of Pamona, Mori, and Minahasa descent. They included many civil servants, retired military, and other middle-class Protestants.

41 Noorduyn, A Critical Survey, pp. 134-135.

$42 \mathrm{Al}$-Khaira'at is an Islamic school system that was founded in the early twentieth century by a member of the Al-Jufri clan who migrated from the Middle East. Although the organization is based in Palu, it now has 1,200 branches in eight provinces of eastern Indonesia. 
The injured Muslim youth from Kayamanya fled to a mosque, and group hostilities escalated quickly the following morning. Religious leaders from both sides met and jointly blamed the evil influence of alcohol. They decided to enforce a ban on its sale during Ramadan. Police then began seizing and destroying liquor for sale in the city. Some Muslim youths, however, escalated the property attacks, mainly against establishments owned by Christian Chinese. Protestant youths then became involved in defending the shops. Alcohol was given to them, or hidden, and religious battle lines etched deeper. ${ }^{43}$

Rumors spread to neighboring towns that Poso churches were being burned, and hundreds of Protestant Pamona farmers congregated in the town hall of Tagolu, just seven kilometers south of Poso. The recently assigned Javanese police chief and other city officials assured the Protestants that no churches had been harmed. Yet, on Sunday evening, December 27, scores of machete-armed Pamona from the GKST stronghold of Tentena arrived by truck to reinforce the threatened GKST Protestants of Lombogia. These trucks, which witnesses said were led by the DPRD II representative Herman Parimo, carried members of the Gerakan Pemuda Sulawesi Tengah (GPST), a resurrected version of the Protestant Pamona militia organization dating back to the Permesta period. ${ }^{44}$ Apparently, Parimo had been involved with the original GPST group in his youth. Many Muslims later would blame the initiation of group aggression in Phase One on Parimo's leadership and his anger that Patiro, supported by his Protestant Pamona political faction, was eliminated by Muslim leaders in the early DPRD II nominations for regent. Other Muslim leaders would blame the candidate Patiro directly. ${ }^{45}$ Christians, by contrast, would defend these two men and deem their protective actions fully justified.

The next morning, the Protestant groups, strengthened by reinforcements and armed with homemade weapons, began clashing with Muslims in front of the Poso police barracks. Truckloads of Muslim reinforcements also arrived from the Muslim Bugis and Kaili area of Parigi to the west. ${ }^{46}$ Several town officials and religious leaders tried to negotiate peace between the two uneasy sides but, as soon as authorities left, some Muslim mobs began to attack Protestant and Catholic property, looting and burning homes as well as commercial buildings. Thousands of Poso residents and outsiders were drawn into the rioting, which continued for over a week and spilled beyond the borders of the city to towns along Poso's three major access roads (west, east, and south). During the week of turmoil, nearly two hundred people were injured, mostly Protestants, some tortured by being stabbed, burned, or dragged by ropes from vehicles. Roughly four hundred Protestant and Catholic families saw their houses destroyed. The homes of the Muslim regent, Patanga, and the two Protestant leaders, Patiro and Parimo, reportedly were stormed, although the families were evacuated

\footnotetext{
43 David Rohde, "Indonesia Unraveling?" Foreign Affairs 80,4 (2001): 110-124, esp. p. 117; see also "Kerusuhan di Poso, 79 Orang Luka," Detikcom, December 28, 1998; Reen et al., "Crisis in Poso."

44 "Kota Poso Masih Mencekam," Kompas, December 29, 1998; on the GPST, see Schrauwers, Colonial 'Reformation,' p. 83.

45 Yahya Al-Amri, "Panglima Perang Pasukan Putih," yahoo.com.group/sabili2000, June 29, 2000.

46 "Poso More Restless Again," Kompas, December 29, 1998.
} 
safely. 47 The bus terminal along with stores, restaurants, hotels, and vehicles owned mainly by Chinese Protestants and Catholics were burned down. Some Muslim city officials later claimed they made futile attempts to quiet the crowds by calling on them to stop fighting, but other reports indicate that employees from those same officials' offices urged the mobs towards arson and violence.

Even in the first days of fighting, Poso Protestants sending personal reports claimed that Protestants had long been "stepped on" (diinjak-injak), and for that reason, they feared that their community might become vengeful. Many were convinced that the violence was provoked from outside the region. One writer called for prayers that Poso Protestants would not be trapped into revenge because "whenever Protestants are provoked [terpancing], it is exactly that which is hoped for by provocateurs [para provokator] whose quarrels arrive from outside Central Sulawesi." 48

Governor Paliudju was contacted in Palu for assistance within a day of the first communal bloodshed, but as one local Protestant commented immediately, "we cannot hope for very much from the security forces [aparat keamanan]." 49 The Poso police, as well as reinforcements sent from Palu, were unable or unwilling to control the situation. Some police would later explain that they hesitated to get involved, noting the influx of non-local mobs, both Protestant and Muslim, unwilling to heed calls for restraint. They did claim, however, to have sealed all roads to Poso from further rogue militias. ${ }^{50}$

By the end of Christmas week, Protestant supporters who came from the highlands and Muslim supporters from the coastal towns retreated, as drenching rains turned Poso into a sea of mud, and fighting diminished. Governor Paliudju then arrived to discuss matters with local political and religious leaders in the office of the regent, Arief Patanga. ${ }^{51}$ Muslim leaders vehemently demanded arrests of the Protestant leaders, and news reports announced a search for Herman Parimo, the suspected "mastermind" of the riots. 52

One of the factors that exacerbated tensions was the appearance of fliers, banners, and graffiti that attacked Parimo and Patiro, the regent candidate he supported. These messages began before December 24, and they multiplied thereafter. A banner demanding that these men be hanged was posted for over a month on a mosque in the Kayamanya neighborhood. Christian analysts considered the anonymous message campaign to have been a successful effort to intimidate the Protestant Pamona faction, inflame the Muslim Bugis factions, and prevent Patiro from being selected as regent. ${ }^{53}$

\footnotetext{
47 Johan Budi S.P., Iwan Setiawan, Darlis Muhammad, "Tragedi Poso Duka Kita Bersama," Tempo, June 12-18, 2000; also Kie-Eng Go, "Political Agenda."

48 Confidential Protestant e-mail source, December 28, 1998.

49 Confidential Protestant e-mail source, December 30, 1998.

50 "Kerusuhan di Poso, 79 Orang Luka," Detikcom, December 28, 1998; "Petugas Keamanan Tutup Semua Pintu Masuk ke Poso," Kompas, December 29, 1998.

51 "Hujan Deras, Kerusuhan Poso Reda," Detikcom, December 29, 1998.

52 “Petugas Keamanan," Kompas, December 29, 1998, and "In Poso is Formed a Joint Security Force," Kompas, December 30, 1998.

53 Kie-Eng Go, "Political Agenda"; also, M. Hartingsih, "Memadamkan Api Dalam Sekam," Kompas, December 1, 2000.
} 
On December 30, Major General Marasabessy, an Ambonese Muslim leading Sulawesi's Wirabuana Military Command, announced that the four days of riots had not been caused by disputes among ethnic or religious groups (suku, agama, ras, antara golongan, or SARA), or by the political fight for the regent position. Rather, eight unidentified individuals (oknum) had provoked the disturbances. Now that these eight troublemakers were in his custody, everything was under control, he said. ${ }^{4}$ The military's official pronouncements not only provided the requisite "good news" to Jakarta, but also focused on a "de-ideologized" criminality that denied the presence of any regional social problems. On January 2, 1999, Marasabessy reported on local Sulawesi television that the eight Protestants he had just arrested were responsible for the riots..$^{55}$ No Muslims were prosecuted for the vandalism, arson, or battery, and this seemingly one-sided, religiously partisan, reaction caused Protestants to be increasingly dissatisfied, though they did not retaliate at that time.

Herman Parimo was jailed for leading the Pamona youth group to violence, although his candidate Patiro was exonerated of incitement to violence by a gubernatorial investigation. Patiro's exoneration and later reassignment to the provincial administration (Pemda I) further angered Poso Muslims convinced of his guilt. In July 1999, after seven months in jail without a trial, Parimo engaged in a fourday hunger strike to protest his situation. On August 30,1999, he was brought to trial in Palu. ${ }^{56}$ Parimo, age sixty-four, was convicted and sentenced to fourteen years imprisonment. While his case was on appeal, however, he became ill, underwent hospital treatment in Makassar, and died in April 2000.57

Parimo's supporters protested that he was framed, while those who disseminated the slanderous leaflets that provoked violence from Protestants and Muslims went free. A May 24, 1999 letter to Governor Paliudju by a relative of Parimo's wife, a Protestant Pamona civil servant named Ir. A. L. Lateka, argued that the lame-duck regent, Arief Patanga, was really responsible for provoking the riots. ${ }^{58}$ Poso police chief Woerjantono indeed eventually linked the Muslim regent's younger brother (adik kandung), Agfar Patanga, to the flier campaign and charged him with the crime of incitement to violence. Christians note angrily that, although ultimately convicted and sentenced to two years in prison, Agfar Patanga never served any jail time and continued work as a civil servant with a reassigned position. Reportedly, Arief Patanga and his supporters attempted to interfere in Agfar's trial to prevent the conviction and incarceration. Possibly for this reason, and because of ties to his

54 "Kerusuhan Poso Akibat Provokasi 8 Oknum," Detikcom, December 30, 1998. Marasabessy was a close ally of Wiranto and similarly opposed to the depoliticization of the military favored by Wahid. See The Editors, "Current Data on the Indonesian Military Elite."

55 Kie-Eng Go, "Political Agenda."

56 "Daerah Sekilas," Kompas, April 27, 1999; "Kilasan Hukum," Kompas, July 12, 1999; "Daerah Sekilas," Kompas, September 1, 1999.

57 One article in an Al-Khaira' at-affiliated Palu tabloid claimed that Parimo's death during medical treatment was suspicious, and it implied he is still alive and in hiding; "Teka-teki Kematian Herman Parimo," Mal, Week 4, July 2000, p. 11.

58 Budi, Setiawan, and Muhammad, "Tragedi Poso." According to Gatra, June 9, 2000, and Mal, Week 4, July 2000, Lateka worked in the Central Sulawesi Coordination Agency for Investments (Badan Koordinasi Penanaman Modal or BKPMD Sulawesi Tengah). 
brother's leafleting campaign, Arief Patanga was removed from the regent post prematurely by Governor Paliudju in June 1999.59

In June 1999, Indonesia also held its first free elections in over three decades, and Abdurrahman Wahid was selected president by the MPR (Majelis Permusyawaratan Rakyat, People's Consultative Assembly) in October. As mentioned above, Golkar won the largest percentage of Poso regency votes in the 1999 elections. The Protestant Patiro and the Muslim, PPP-backed, Ladjalani were eliminated from the nominations. The Golkar party instead supported, and the governor installed, Muin Pusadan from the Muslim-majority Bungku area, located about two hundred kilometers southeast of Poso. The new regional secretary, Malik Syahadat, and the new speaker of the DPRD II, Akram Kamaruddin, also were Golkar-affiliated Muslims from Bungku, a center of the brand new Morowali Regency created by Habibie in September 1999.

This political turn of events disappointed not only the Pamona and other Christians who had supported Patiro, but also the Muslim supporters of Ladjalani, who insisted that he at least should receive the regional secretary position. ${ }^{60}$ In midApril, 2000, a PPP-affiliated, Muslim DPRD I member named Hailani Umar predicted more violence in Poso. ${ }^{61} \mathrm{He}$ indicated that the Muslim population of Poso was furious and would riot again if Ladjalani, who was head of Central Sulawesi's Agency for Regional Development (Ketua Badan Pembangunan Daerah), was not elevated to the regional secretary post. In fact, however, Ladjalani was demoted to become the assistant head of Central Sulawesi's Agency for Regional Development-not the promotion his supporters had demanded. ${ }^{62}$ Umar's forecast of impending violence was reported in the Palu daily newspaper Mercusuar on April 15, 2000, and Phase Two began the following day.

\section{Phase Two}

The brawl that began Phase Two again involved drunken youths, one Protestant and one Muslim, who began fighting at Poso's central bus terminal. ${ }^{63}$ The Muslim boy claimed when he returned home to Kayamanya that the knife wound on his arm was the work of a Protestant "outsider," probably from Manado. The next day, Muslims from Kayamanya pursued the alleged attacker in nearby neighborhoods, finally knifing

${ }^{59}$ His removal is reported but unexplained by "Daerah Sekilas," Kompas, June 16, 1999.

60 Budi, Setiawan, and Muhammad, "Tragedi Poso."

61 Iwan Triono, "Buntut Kerusuhan Poso Wartawan Menara Calon Tersangka," Detikcom, April 28, 2000; and Agus Dwi Prabowo, "Setelah Kerusuhan Kini Banyak Warga Poso Belum Kembali," Bidikcom, April $28,2000$.

62 Andono Wibisono, "Poso Bakal Rusuh Kembali," Mercusuar, April 15, 2000, p. 1; "Buntut Kerusuhan Poso: Wartawan Diperiksa sebagai Saksi," Kompas, April 29, 2000.

63 Reen et al., "Crisis in Poso"; Paul Dillon, "This Entire Situation Could Explode at Any Moment: Holy War Massacre," The Toronto Star, July 1, 2000; and "Poso (Sulawesi Tengah) Rusuh Lagi," Eskol-Net, April 18, 2000. In Central Sulawesi, it is not just Christians and preman Muslims who sometimes drink alcohol. Indigenous groups formerly drank palm wine (fermented to widely varying strengths), especially at holidays, and some villagers still do despite disapproval by Muslim and some Protestant clerics. In addition to rural homemade brews, both Bir Bintang and a commercially distilled liquor named Cap Tikus sell well in urban areas, even to some Muslim middle-class men and civil servants. 
his Toraja father from behind. Angry crowds assembled, more people were injured, and Muslims began to burn down Protestants' houses that night. Many Protestants whose houses were plundered and burned in the next few days fled to the Protestant hillsides above Lombogia or south by road to Tentena. ${ }^{64}$ Attacked ethnic Chinese also fled to towns where they had relatives, which sometimes was to other provinces or islands.

Poso police chief Woerjantono called in a unit of the Brimob (riot-control Mobil Brigade) from Palu, which tried to restrain Muslim groups attempting to burn Protestant churches and homes. Unable to control the rioters, Brimob personnel fired live ammunition into the crowd and killed three Muslims. When Governor Paliudju came to Poso the next day to promote peace, incensed Muslim leaders led by a businessman named Aliansah Tompo (also called Maro) met him in Regent Pusadan's office and presented him with a set of demands "in the name of the people." They insisted that Chief Woerjantono be fired, that the Brimob unit be sent back to Palu, that the lawsuit against Agfar Patanga be stopped, and that Ladjalani be given the regional secretary position. At the time, Woerjantono was investigating alleged fraud in a government farm loan program (Kredit Usaha Tani, or KUT) by both Tompo and Patanga, just as Patanga's trial was due to resume the following week. ${ }^{65}$

The Brimob unit was sent home in an effort to reduce tensions but, soon afterwards, house burnings continued. There also was an incident where an unidentified person was found stabbed to death beside a Muslim hat (kopiah) on the street of a Protestant neighborhood. Some sources suggest the corpse, which was mysteriously discovered by unrecognizable people, had been planted at the spot by Muslim provocateurs. In any case, outraged Muslims, reinforced by outsiders who arrived from coastal areas east and west of Poso, began burning more houses and churches as well as a PDIP headquarters. ${ }^{66}$ Both Muslim and Protestant groups reportedly used "handy-talkies" and other electronic communication devices to coordinate with their community networks. Muslim groups then began a "sweeping" operation in which those traveling through Muslim neighborhoods were inspected for identity cards (Kartu Tanda Penduduk, or KTP) or other indications of their religion. Some Protestants were pulled from vehicles and publicly slashed to death. Muslim groups also began sewing and wearing white headbands to recognize each other.

Six hundred army personnel were sent from Makassar by the Wirabuana Military Command but, within days, thirty-eight Protestants were reported injured and seven killed. ${ }^{67}$ Almost seven hundred houses belonging to Protestants and Catholics were destroyed, along with four Protestant church buildings, three Protestant schools, and one police dormitory. Reportedly, Christians did not do much to fight back, but rather fled their newly rebuilt homes because they still were terrorized by the events of

64 WALHI-Sulteng (Wahana Lingkungan Hidup Indonesia-Sulawesi Tengah) emergency team, unpublished report on the Poso riots, circulated August 2000; also, "Situasi Poso," Eskol-Net, April 18, 2000.

65 WALHI-Sulteng, unpublished report, and David Rohde, unpublished manuscript dated October 30, 2000.

66 These Muslim coastal areas included Parigi, Tokorondo, Ampana, and Uekuli; "Situasi Poso," Eskol-Net, April 18, 2000; WALHI-Sulteng, unpublished report.

67 "Poso Crippled as Unrest Continues Despite Deployment of More Troops," Jakarta Post, April 19, 2000. 
1998. ${ }^{68}$ When Governor Paliudju met with Poso police, religious leaders, and Regent Pusadan, he announced he would set aside money for refugees, but he warned the mainly Protestants victims of the riots not to take revenge because it would only worsen the situation. ${ }^{69}$ In a comment designed to prevent vendettas against Poso Muslims and yet resonate with local Protestant theology, Paliudju said "Let it be God alone who avenges their [the attackers'] actions" (Biarlah Tuhan yang membalas perbuatan mereka). Seemingly, God alone was being asked to investigate and punish the attackers because only twenty-one witnesses were questioned and, as in Phase One, few suspects were taken into custody. With no significant investigations pending, Phase Two was declared officially over by Central Sulawesi police on May 3, just three weeks before the start of Phase Three. ${ }^{70}$

\section{Phase Three}

The devastating Third Phase began on May 23, 2000 and continued actively through July 2000. An estimated three hundred to eight hundred people were killed, this time mostly Muslims. Thousands more homes, also owned mostly by Muslims, were destroyed. The flight of refugees nearly emptied the city and surrounding towns while it further burdened refugee destinations such as Palu, Parigi, Tentena, Napu, and Manado. Burned and decapitated corpses floated down the Poso River for weeks; more were discovered in ravines and mass graves.

Phase Three was seen by many Christians as retribution for home, church, and personal attacks that had been staged by Muslims for one and a half years with impunity. A nighttime strike was planned against the Kayamanya neighborhood by about a dozen black-clad "ninjas."71 Their targets were Muslims they held responsible for the violence of Phase Two. Most news reports assign leadership of the ninja strike to Fabianus Tibo, but Lateka also was named in Poso as the leader of the nighttime strike. ${ }^{72}$ Lateka was the Protestant Pamona civil servant who reportedly wrote the May 24, 1999 letter to the governor claiming that the Muslim regent, Arief Patanga (rather than Lateka's jailed in-law, Parimo) was responsible for inciting the first Poso rioting. In any case, the masked ninjas apparently ran into a policeman before reaching their target. In the ensuing scuffle, the gang killed three Muslims, including a police officer named Kamaruddin. They injured several others, and then hid inside a dormitory of the Santa Theresia Catholic Church at nearby Moengko. This church was attended mainly by ethnic Chinese and Minahasans, but also by migrants from Flores.

Fabianus (a.k.a. Cornelius) Tibo was born circa 1945 in Flores, moved as a teenager to Maluku, and then became a longshoreman in Banggai, where he married and had three children. Afterwards he migrated to the Poso region to work on a palm oil

68 "PGI Asks Govt to Act on Poso Rioting," Jakarta Post, April 24, 2000; "Situasi Poso," Eskol-Net April 18, 2000.

69 "Kerusuhan Poso Rumah Penduduk Mulai Dijarah," Kompas, April 19, 2000.

70 Lukmanul Hakim, "Kapolda Sulteng: Kerugian Kerusuhan Poso Rp. 10 M," Detikcom, May 3, 2000.

71 On the phenomenon of Javanese "ninja" killers, see James T. Siegel, "Suharto, Witches," Indonesia 71 (April 2001): 27-78.

72 David Rohde, personal communication, March 13, 2001. 
plantation. In 1978, he entered the transmigration settlement in Beteleme (then in Poso Regency, now in Morowali Regency), where he worked on a rubber plantation. Tibo is widely characterized in news reports as a recidivist criminal (residivis)-he was jailed from 1990-1995 for killing a man in Beteleme-or even a mercenary killer. As a Catholic outsider, he might have been hired to kill either Protestants or Muslims. Tibo, however, claimed he came to the Moengko church with other concerned Flores citizens because of news that all Poso churches were on the verge of attack. Tibo already knew the church's pastor and several ethnic Flores congregation members. The fact that witnesses described Tibo's followers as clothed in black, however, suggests their arrival in the area was more than a concerned social visit.

Authorities arrived at the church looking for the reported ninjas, disarmed the Christians, and negotiated with Tibo to bring them to the police station for questioning. When Muslim crowds threatened to ignore the police and lynch the gang, however, the Christian attackers fled along with frightened church staff out the back of the church. All but a few of the group escaped, and the church was burned down. Some say the arson took place as the Muslims tried to seize the Christian gang; others say it happened after the escape, as a response by the frustrated crowd. In any case, more fighting between Protestant and Muslim groups elsewhere in Poso city began the same day. ${ }^{73}$

The next day, Governor Paliudju announced that everything in Poso was under control and that three of the estimated thirteen provocateurs had been caught. Paliudju seemed confident that everything could be blamed on the "ninja" gang of "outsiders," led by Tibo, and that the criminals who escaped would be captured soon. The governor added that the disturbances likely were timed to draw attention away from the upcoming national Qur'an recital competition in Palu. ${ }^{74}$ The construction of buildings and preparation of roads for the competition had drawn extraordinary national funding to Palu. The national media attention to Palu and influx of money for infrastructural improvements made the event a source of pride and interest among Muslims and Protestants in the provincial capital-although both religious communities also became apprehensive about the possibility that religious attacks might occur during the event, which drew many "outsiders."

Tibo and Lateka were not arrested quickly, however. Another church was burned, and more skirmishes occurred between Christian "red troops" (pasukan merah) and Muslim "white troops" (pasukan putih). The different Christian attack squads became known as "red bats" (kelelawar merah), black bats (kelelawar hitam), and "masks" (topeng). As the fighting continued over the next few days, more neighborhoods were burned, cacao farms were attacked with chain saws, rumors spread that the public drinking water had been poisoned, and the number of refugees increased.

The most infamous attack on Muslims began on May 28. Tibo and his group, which included two other Flores Catholics without criminal records named Dominggus da Silva Soares and Don Marinus Riwu, surrounded Sintuwu Lemba village just south of

\footnotetext{
73 WALHI-Sulteng, unpublished report; also, compare Rita Uli H., "Poso Masih Mengkhwatirkan," Detikcom, May 25, 2000, with "Kronologi Kerusahan Terakhir (23 Mei-6 Juni)," Tempo, June 12-18, 2000.

74 "Poso Rusuh Lagi Tiga Tewas," Jawa Post, May 24, 2000; A. Era, "3 Orang Tertangkap Pasukan Ninja Beraksi di Poso," Detikcom, May 24, 2000.
} 
Poso. The area is known more generally by its location as Kilo Nine (Kilo Sembilan). This Javanese transmigration settlement of prospering cacao farmers was a focus of jealousy for the neighboring Protestant Pamona villagers of Tagolu who had watched their ancestral holdings shrink as the migrants continued to purchase more land. When Tibo's group attacked, women and children fled into the forest but many were soon captured and held hostage. About seventy of the village men ran and hid in a nearby Muslim boarding school, Pesantren Wali Songo. Tibo's group discovered the men, Tibo was injured in a scuffle, and his followers retaliated by executing those who surrendered. Some of the Muslims escaped, but Tibo's group sent out raiding parties, which brought some captives back to the Tagolu community hall for torture, and killed and tossed others directly into the Poso River. ${ }^{75}$ The captured Javanese women and children were not killed, but were held by Tibo's group for several days at a house in Tamboro Village, just south of Sintuwu Lemba. One of the women later testified that some were subjected to strip searches and inspections of their vaginas by Dominggus, who claimed to search for hidden Javanese amulets. ${ }^{76}$

In the days following the Kilo Nine atrocities, more Muslim settlements around Poso were attacked, and Governor Paliudju publicly named Lateka as the "intellectual" responsible for the Third Phase violence. Newspapers reported that Lateka had claimed responsibility by telephone, saying he financed the anti-Muslim revenge with 30 million rupiah. ${ }^{77}$ On June 2, 2000, hundreds of Pamona Protestants again fought with Muslims in the Poso neighborhood of Kayamanya, and Lateka was shot and killed. ${ }^{78}$ The bodies of Lateka and a Protestant woman named Paulina Dai were delivered to the house of a Muslim Al-Khaira'at leader. ${ }^{79}$ GKST Protestant leaders later claimed Lateka's body was chopped into small pieces. In the following days, dozens of predominantly Muslim villages along the road running west towards Parigi and Palu, as well as the road running east to Ampana, were attacked and burned, effectively closing Poso's major transportation and communication system. ${ }^{80}$ Down the southern road, at Tentena, Muslim stores and homes also were attacked.

Once news of the Muslim deaths and floating corpses spread, the Central Sulawesi Student Militia (Laskar Mahasiswa Sulteng), consisting mainly of Muhammadiyah and Al-khaira'at pupils, demanded that the governor stop the "attacks on Muslims." Muslim refugees complained that police did not even appear at the sites of ongoing

75 David Rohde, unpublished manuscript; Reen et al., "Crisis in Poso"; Poso Menangis, Ratusan Nyawa Melayang di Pesantren Wali Songo," Kompas, June 13, 2000; Lindsay Murdoch, "Religious Killing Fields Spread across the Ugly New Indonesia," Sydney Morning Herald, June 29, 2000.

76 "Kesaksian Empat Janda, 10 Hari Ditawan di Hutan," Al Bunyan, September 26, 2000; "Poso Massacre Witness Slaps Suspects in Court," Indonesian Observer, February 6, 2001. On magical power (ilmu) used in the Poso conflicts, see Lorraine V. Aragon, "Missions and Omissions of the Supernatural," paper for the American Anthropological Association, December 2, 2001, Washington, DC.

77 Tempo Interaktif, May 30, 2000; “Dalangnya Bernama A. L. Lateka?,” Jawa Pos, May 30, 2000.

78 "Kerusuhan Poso Pecah Lagi Jumat Pagi, Dua Tewas," Suara Pembaruan, June 2, 2000.

${ }^{79}$ Habib Saleh Al Idrus (Pemimpin Majelis Zikir Nurkhaerat Poso), "Benteng Muslim Sudah Saya Dirikan," Formasi No. 50, August 2000, p. 6; Anton Bahtiar Rifa'i, Mustopa, and Aldrin Kd., "Kota Mati yang Terkepung," Forum Keadilan 11, June 18, 2000, p. 88.

80 A. Era, "Polisi Tembus Barikade Warga, Situasi Poso Berangsur Pulih," Detikcom, June 5, 2000. 
vandalism. ${ }^{81}$ The governor then asked Jakarta for more army assistance. Fifteen hundred soldiers, ten tanks, and a combat unit were sent from the Wirabuana Military Command in Makassar. ${ }^{82}$

Additional Muslim pressure came from the Indonesian Muslim University in Makassar, where students began a "sweeping" operation in the city, checking identity cards and beating non-Muslim passersby. The students claimed they were demonstrating solidarity with Poso Muslims. They also expressed their frustration with the Wirabuana Commander who would not meet and hear their demands. ${ }^{83} \mathrm{~A}$ South Sulawesi member of the Council of Indonesian Muslim Leaders (Majelis Ulama Indonesia, or MUI), K. H. Habib Sanggah, called for wealthy individuals "to fund the Muslim side" because the army and local police were doing nothing to assist them.

During June, there was continued Muslim outrage and suspicion cast upon a dazzling array of culprits. Suspects implicated through news media included the entire Poso security "apparatus," the wife of a Jakarta conglomerate leader (isteri konglomerat di Jakarta) who purportedly had assisted the now-slain Lateka to obtain weapons, Indonesian Army personnel (TNI) who had smuggled weapons, and even a German tourist traveling in South Sulawesi. ${ }^{84}$ Despite the widespread allegations that military issue or imported weapons had been involved in Phase Three, there remains little evidence that anything beyond homemade knives, bombs, and guns-some designed to look, but not function, like commercial automatic weapons-were used. Many of the killing and "torture devices" of Poso are items otherwise used for non-aggressive, if ecologically unsound and dangerous, subsistence activities. For instance, bottle bombs made from urea fertilizer and match heads have been used illegally for decades to increase fish catches along Sulawesi's coasts. The cottage industry producing these bombs, however, much of it based in Buton Regency, has increased exponentially with demand from the Poso and Ambon conflicts. ${ }^{85}$

On June 6, a Christian "red group" battled with police just east of Poso, and over sixty more people were killed. The next day local police captured nine unnamed "provocateurs" and advised citizens to ignore rumors and leave everything to the security forces. ${ }^{86}$ As late as July, Muslims still were disappearing, more bodies were discovered in mass graves, and a few army men were interrogated. The Council of

\footnotetext{
81 "Poso Dalam Patawan: Mahasiswa Tuntut Diberlakukan DOM," Tempo Interaktif, May 31, 2000.

82 “Kodam Kirim 1500 Tentara ke Poso, Detikcom, May 30, 2000.

83 Aulia Andri Swastika and Lyndal Meehan, "Makassar Students 'Sweep' for ID Cards," Detikworld, June 1, 2000.

84 Literally, aparat di Korem, Komando Resort Militer, Kodim, Komando Distrik Militer, serta Polres, Polisi Resort; see "Kerusuhan di Poso," Suara Merdeka, June 5, 2000; Esther Permatasari, "Penyelundupan Senjata ke Poso Sudah Lama Diketahui," Detikcom, June 9, 2000; "Kerusuhan di Poso Isteri Konglomerat Diduga Pasok Dana," Suara Merdeka, June 5, 2000; Budi, Setiawan, and Muhammad, "Tragedi Poso"; "Kodam Wirabuana Tangkap Provokator Asing di Palopo," Jawa Pos, June 12, 2000; Iwan Triono, "Reiche Bukan Provokator Poso," Detikcom, June 19, 2000.

85 Arif Zulkifli, Dedy Kurniawan, and Darlis Muhammed, "Bombs from a Faraway Island," Tempo Interaktif, August 21-27, 2001.

86 A. Era, "Di Poso, Kelompok Merah Baku Tembak dengan Aparat," Detikcom, June 6, 2000; Lukmanul Hakim, "Kerusuhan Poso, Polisi Tangkap 9 Provokator," Detikcom, June 7, 2000; "Kronologi Kerusuhan Terakhir (23 Mei-6 Juni).".
} 
Indonesian Muslim Leaders scolded the police for their inability to catch Christian gang leaders. ${ }^{87}$ In mid-July, 124 people suspected of involvement in the Christian "red group" were arrested well southeast of Poso in the Kolonedale area of Morowali Regency. ${ }^{88}$ Then, on July 25 , Tibo was found hiding in the same area; he was captured and sent to jail in Palu. ${ }^{89}$

Other "red group" members captured and investigated by police included Dominggus da Silva Soares, Don Marinus Riwu (also referred to as Martianus or Rinus), Fery (also referred to as Hery), Leonardus, Alexius, and Rahman, mostly other ethnic Flores Catholics who resided at or near Beteleme, Morowali Regency. ${ }^{90}$ Witnesses claimed to have observed these individuals slaughtering Muslim victims. According to later trial witnesses, Tibo had prepared a seven-hundred-man militia over the course of a month at a training camp at Kelei Village (near to Tentena in the Pamona Utara District), and the training was funded by retired army officers, or other outsiders. ${ }^{91}$ Tibo initially confessed that he personally executed about forty of the hundreds who were thrown into the Poso River or other mass graves, but later retracted this admission. His lawyer claimed Tibo was less important than four or five other leaders or "generals" (jenderal). ${ }^{92}$ Witnesses to this statement explained that, when Tibo's lawyer mentioned "generals," he and Tibo, whom he represented, were speaking metaphorically of Protestant Poso leaders such as Lateka, but many newspaper readers assumed they were referring to "red" or anti-Muslim army generals in Jakarta. Moreover, the Indonesian media focus on "provocateurs," "intellectuals," "ninjas," and "masses," (provokator, intelektual, ninja, massa) obfuscated the power struggles, patron-client economic links, and concepts of identity operating in Sulawesi at the kinship, village, and religious congregation level.

\section{Attempted Reconciliation, the Tibo Trial, and the Onset of Phase Four}

In August 2000, the governors of Central, North, and South Sulawesi met in Tentena to sign a "peace accord" aimed at reassuring refugees that they could return home safely and would receive some government aid. ${ }^{93}$ Yet, ministers from the Central Sulawesi Protestant Church (GKST) and related Crisis Center in Tentena, as well as Javanese Muslims who had fled to South Sulawesi, felt uninvolved and unconvinced. On August 22, President Wahid himself attended a peace meeting with invited Poso leaders. This neo-traditional adat ritual, complete with the burial of a buffalo head,

87 "Tiga Anggota TNI Asal Kodim Poso Ditahan Polisi Militer," Kompas, July 5, 2000; "Ulama Sesalkan Polisi Lambat Tangkap Perusuh di Poso," Kompas, July 6, 2000; "211 Confirmed Dead in Poso Clashes," Jakarta Post, July 6, 2000.

88 "124 Arrested over Latest Poso Violence," Jakarta Post, July 10, 2000.

89 "Panglima Perang Poso Ditangkap," Kompas, July 27, 2000.

90 "Tokoh Perusuh di Poso Terancam Pidana Mati," Analisa, August 4, 2000; "Three More Arrested over Poso Killings," Jakarta Post, August 16, 2000.

91 "Poso Rioters Got Supply of Guns," Jakarta Post, January 30, 2001.

92 "Witnesses Testify about Massacre in Poso," Jakarta Post, February 6, 2001; "Palu," Tempo, July 6 August 2000, p. 37; "Tibo Ungkap Lima Jenderal Tertingginya," Mercusuar, July 29, 2000, p. 1.

93 "Sulawesi Governors Sign Poso Peace Deal," Jakarta Post, August 14, 2000. 
reportedly signified the leaders' resolve to end their animosities. ${ }^{94}$ The ceremony was described with a Pamona phrase, Sintuwu Maroso, which translates as "Strong When United" or "Strong Union." This phrase is the official slogan of the Pamona Utara district, although its widespread use in government signs now seems incongruous given the bloody fighting in the region. The term originally implied ongoing economic exchange, somewhat comparable to gotong royong in Java. Ironically, one of the structural problems of the Poso area-and probably several other communal conflict regions-is that lowlanders (Muslims) and highlanders (Protestants) no longer symbiotically exchange coastal and forest products as they once did. Instead, they too often compete head-on for access to the same road-side land, cash-crop sales, and central government development funds, a by-product of Indonesia's historical experience of nationalization and globalization. Comparable to many others involved in contemporary ethnonationalist conflicts, Poso Protestants and Muslims increasingly have "forgotten" the positive aspects of their shared historical and cultural bonds, while their recent experience of injury promotes the systematic creation of hatred and revives animosities from the 1950 s rebellions. ${ }^{95}$

Despite several high-profile reconciliation efforts in late 2000, public criticisms continued about biased processes of investigation, recurring incidents of Poso violence, and dwindling food supplies in the Palu and other refugee camps, from which tens of thousands of residents understandably were reluctant to depart. Although the Indonesian Red Cross chairman urged administrators not to segregate refugees along religious lines, de facto segregation occurred in the camps, and most Christians and Muslims fled to towns where their own religion was in the majority. ${ }^{96}$ The refugee camps and resettlement process contributed not only to Indonesia's "domestic conflict" economic problems, but also to the nation's increasing "ghetto-ization" of religious communities.

As Poso burned and refugees poured in, Palu remained calm, if tense, throughout the summer of 2000. Most Muslim and Protestant leaders in Palu called for peace and restraint. They also made efforts to assist the ten thousand to twenty thousand refugees who amassed in Palu's Gawalise sports stadium and in the barracks for nonpermanent civil servants from Poso (Mess Pemda Poso).${ }^{97}$ By October, however, Muslim groups began demonstrating in Palu, demanding that Tibo quickly be tried and executed.

The trial of Fabianus Tibo and two of his accomplices, Dominggus Soares Da Silva, and Don Marinus Riwu, ran from December 2000 to April 2001. Provincial Muslim leaders and Palu protesters clamored for their execution, while Protestant leaders argued that justice would only be complete if perpetrators of the First and Second

\footnotetext{
94 "Warga Poso Sepakat Damai," Kompas, August 23, 2000; "Poso Leaders Bury Hatchets for Peace Before Gus Dur," Jakarta Post, August 23, 2000.

95 Das, "Specificities: Official Narratives," pp. 113-114.

96 "Don't Separate Poso Refugees: Mar'ie," Jakarta Post, June 26, 2000; "Over 20,000 Refugees Afraid to Go Home," Indonesian Observer, June 21, 2000; "Poso Refugees Miss Their Homes," Jakarta Post, September 11, 2000; "Poso Refugees Refuse to Go Home," Indonesian Observer, November 29, 2000.

97 "Tokoh Agama Palu Serukan Kedamaian," Kompas, June 9, 2000.
} 
Phases of the conflict also were prosecuted..$^{98}$ Only the trial of Tibo and accomplices moved forward, with prosecutors demanding the death penalty. By January 2001, continuous sporadic violence in the Poso Regency not only was noticeable, but seemed to worsen. Households and religious buildings were attacked, small bombs exploded, suspected bombers were assailed, and police posts were targeted as the Tibo trial concluded. ${ }^{99}$

The trial itself was a dramatic affair with witnesses for the prosecution claiming that helicopters supplied Tibo's training camp with M-16 rifles from Manado and guns made in the Philippines. A Javanese woman who was held hostage after the raid at Sintuwu Lemba (Kilo Nine) suddenly slapped the faces of the defendants before telling her story of the vaginal inspection. The reigning Poso regent, Muin Pusadan, came to testify, and he laid the blame squarely on the backs of Tibo and the slain Lateka. The three defendants denied all the main charges and stated that prosecution witnesses were lying. Enraged and grief-stricken Muslim men and women threatened the defendants and their police escorts on the way to and from the Palu courtroom. ${ }^{100}$

On April 5, 2001, Judge Soedarmo convicted all three defendants of premeditated murders on three separate dates at three separate locations. ${ }^{101}$ The judge considered the defendants to be without remorse and imposed the death penalty, further exciting the court audience. During the hearings, Tibo reportedly named sixteen other persons responsible for the violence. Among those named were two Protestant officials living in Palu. One was Yahya Patiro, the failed candidate for regent who was exonerated and later became a gubernatorial assistant administrator (Asistan Administrasi Gubernor). The other was Edi Bungkundapu, secretary at the DPRD I. Both denied wrongdoing, and Bungkundapu claimed simply that his political enemies were trying to ruin him. Patiro's home in Palu was stormed by angry Muslims, but the owners already had fled, reportedly to the airport. ${ }^{102}$

Some news reports noted that the trial of Tibo and company was unprecedented, being the first time a court passed a death sentence on persons involved in any of Indonesia's recent riots. ${ }^{103}$ This implied that the state had partially achieved longsought control over ethnoreligious violence, one of Indonesia's many recent forms of unacceptable disorder. Yet, as Protestant leaders were quick to point out, no Muslim

98 "Death Penalty Demanded for Poso Riot Suspects," Jakarta Past, December 11, 2000; "Christian Youth Group Pleas for Law and Order," Indonesian Observer, October 28, 2000.

99 "Tension Escalates in Poso," Jakarta Post, January 18, 2001; "Provocateurs Play with Fire in Poso Conflict," Indonesian Observer, January 26, 2001; "Armed Mobs Renew Attacks at a Police Post in Poso," Jakarta Post, April 6, 2001; "Poso Remains Tense, Buildings Ablaze," Jakarta Post, April 10, 2001.

100 "Poso Rioters Got Supply of Guns," Jakarta Post, January 30, 2001; "Poso Massacre Witness Slaps Suspects in Court," Indonesian Observer, February 6, 2001; "Widows Vent Anger against Defendants," Jakarta Post, April 12, 2001; "Bupati Poso Tampil Sebagai Saksi," Tempo Interaktif, February 12, 2001.

101 These were: Poso city on May 23, 2000; Sintuwu Lemba, Lage District, on May 28, 2000; and another nearby village in Lage District on May 30, 2000; "Poso Riot Leaders Given Death Sentence," Jakarta Post, April 6, 2001.

102 Arifin A., "Febianus [sic] Tibo Dihukum Mati," Detikcom, April 5, 2001; "Three Men Get Death for Plotting Poso Violence," Jakarta Post, April 6, 2001; "Rumah Pejabat Gubernor Sulteng Diserbu Massa," Gatra, April 5, 2001; "Poso Remains Tense, Buildings Ablaze," Jakarta Post, April 10, 2001.

103 "Widows Vent Anger against Defendants," Jakarta Post, April 12, 2001. 
killers were tried or sentenced, implying that the state was not yet able to provide justice and security to all. Moreover, any hopes for peace and reconciliation in Poso following Tibo's conviction were fleeting. Within days, there were new group attacks on Poso mosques, on an Al-Khaira'at school, on Muslim residents of the Kayamanya neighborhood, and on cacao groves in Muslim villages just south of Poso city. ${ }^{104}$ By late June and early July 2001, there were frequent reports about both Protestant and Muslim villages being attacked, and thousands more fleeing (or again fleeing) the Poso Regency. The term Phase Four increasingly was applied to these now familiar, civil war conditions. ${ }^{105}$

Phase Four reports indicate that the conflict continues on the same ethnic and economic fronts as earlier: first, between mostly Pamona Protestants and mostly Bugis Muslims of Poso City; second, in the cacao groves of rural villages to the south, the places where Javanese and other Muslim migrants have encroached on what many Pamona Protestants still view as their ancestral lands. As in the earlier phases, the Poso police, Brimob from Palu, and TNI units from Makassar have shot or captured a few perpetrators of the attacks, but these forces are unable to stop the violence or earn local residents' confidence that the security forces are neutral parties. And, once again, regency and provincial political posts are part of the dispute. DPRD II leaders from three factions have asked Regent Muin Pusadan and the new Muslim governor, Aminuddin Ponulele, to resign because of their inability to curb the violence. The same (unidentified) legislators also claimed that Pusadan and Ponulele had transgressed popular (clearly Christian) requests when they appointed the Muslim Awad Al-Amri as the newest in a revolving line of regency secretaries. ${ }^{106}$ These demands seemingly ask for a return to the pre-1999 situation, when a Pamona Protestant, Patiro, was given the number-two post as regional secretary, although the regent position itself was awarded to a Muslim, Arief Patanga. Other recent reports, which also promise little hope for reconciliation, include news of attempted weapons smuggling to Central Sulawesi, and a Laskar Jihad team's July reconnaissance visit to Palu and Poso. The Laskar Jihad team met with Tadulako University professors, Governor Ponulele, Poso regent Muin Pusadan, and representatives of MUI and Dewan Dakwah Islamiyah Indonesia (DDII, or Indonesian Council for Islamic Appeals). ${ }^{107}$

\section{Religious Reasoning about the Violence}

Questions remain about how religious ideology is used to interpret and justify communal violence in Central Sulawesi and elsewhere. How is religion uniting some and dividing other Indonesians in a way that makes killing acceptable? Clearly, confidence in God's support is used to justify otherwise unconscionable actions. But,

\footnotetext{
104 Johan Budi S. P. and Regional Contributors (Darlis Muhamed), "Poso: Fanning Suffering's Flames," Tempo, June 26-July 2, 2001.

105 Bina Bektiati, Darlis Muhamed, "Poso Riots Part IV: Poso on the Edge," Tempo, July 10-16, 2001; Crisis Centre GKST (Central Sulawesi Protestant Church Crisis Centre), "Laporan Situasi Poso (2-4 Juli 2001)," Eskol-Net, July 7, 2001; "Gelombang Pengungsi Kembali Mengalir ke Palu," Kompas, July 6, 2001.

106 "Police Troops Shoot Dead Five Attackers in Poso," Jakarta Post, July 6, 2001.

107 "Gun Smuggling Attempt Foiled," Jakarta Post, August 2, 2001; "Laskar Jihad Datang, Kristen Resah," http://wwww.laskarjihad.or.id, accessed at indopubs.com/rarchives/0336.html, August 6, 2001.
} 
how are religious leaders and lay people using scriptural teachings and organizational networks to make sense of the violence? And, how do victims use territorial images to categorize their religious enemies?

In Palu, I spoke with a Muslim refugee family of mixed Bugis and Makasar ancestry who had fled in June 2000 from the village of Tokorondo, northwest of Poso. They had immigrated from South Sulawesi only six years previously when the father was hired to work in the local timber industry. They joined a South Sulawesi immigrant faction within an old Protestant Pamona village. Family members were harvesting cacao when they were forced to evacuate immediately. They said that, by the time they fled their village, they no longer knew who were their friends and who were their enemies (siapa yang kawan, siapa yang lawan), meaning that some of their formerly amiable Protestant neighbors suddenly were burning their houses. They said they now had no reason to return to Poso. They had heard from Bugis refugees who arrived later that their home had been burned to the ground and their cacao trees were all picked. They had heard, and now believed, that Christian mercenaries such as Tibo had been paid a large fee for every Muslim they butchered. They could not (or perhaps would not) say who might have paid such as fee.

In August 2000, the pro-Muslim tabloid Formasi, published in Palu, ran an entire issue portraying the Poso violence as a "scenario of religious coercion" (skenario pemaksaan agama). Muslim leaders interviewed in the tabloid insisted that local Protestants and foreign missionaries were aggressively seeking converts from the Muslim population, using force and terror tactics where necessary. ${ }^{108}$ Muslim refugees I met from Poso, as well as some vocal Muslim leaders, accused Central Sulawesi church leaders of direct involvement in the violence. Many also spoke of national or even international (especially American) "efforts to eliminate the Muslim community from the Poso area" (upaya melenyapkan ummat Islam dari bumi Poso). ${ }^{109}$

I spoke with a Chinese Catholic woman from Poso City whose mother's home been burned down twice, once during Phase One in December 1998, then again in Phase Two in April 2000. After hiding in the hills above Poso and watching Muslim groups burn her home for a second time, the mother fled to her sister's house in North Sulawesi. She reached her destination safely, but the Protestant Toraja man who drove her there later was lynched during a "sweeping" incident, his stomach cut out while angry Muslims burned his car. After that, the mother decided she never would return to Poso. When I asked if her mother recognized the Muslims who burned her house, the woman replied that her mother never used personal names, but always identified the attackers according to their Muslim neighborhood (kelurahan), as in the form, orang Kayamanya. Neighborhoods thus became coded by their primary religious affiliations as part of the ongoing process of religious territorialization.

108 Formasi, No. 50, August 2000; see especially Hadi, Djamaluddin, "Pemaksaan Agama Adalah Kejahatan HAM," p. 4; and Waru, Darwis, and Zainul Hikam, "Bayang-bayang Missionaris dalam Poso Berdarah," pp. 4-5.

${ }^{109}$ Haryono, Munanshar, and Pambudi, "Jejak Kelalawar Hitam, Pembantai Muslim Poso," Majalah Suara Hidayatullah, July 2000; also, "Laporan Telpon Poso, Sulteng," Media.isnet.org from Atsari.virtualave.net/Salafy-net, June 6, 2000. 
Many Central Sulawesi Protestants explained the anti-Muslim vengeance in Phase Three in these biblical terms: Poso Protestants had turned their cheeks twice (in Phases One and Two), but then had no more cheeks left to turn. Some Muslim leaders also analyzed the issue of retaliation in scriptural terms. H.S. Saggaf Aljufri, a leader of the region's Al-Khaira'at organization and regional chair of the Council of Indonesian Muslim Leaders, agreed that Poso Muslims had reacted too harshly during Phase Two. He said that Islam permits striking back once for every blow received, but Poso Muslims had struck back three or four times as hard when they attacked and burned Christian neighborhoods. ${ }^{110}$ Such expressions of regret, acceptance of responsibility, or arguments for moderation have been rare among Poso's religious leaders from either side.

Many Central Sulawesi Muslims and Christians remained baffled by the Poso events, and assumed that only the unfathomable wickedness of criminals such as Tibo could explain the violence. Some Protestants told me that Tibo could not really be a Christian if he were able to commit the acts of which he was accused.111 Other Protestants, however, saw in the peculiar sequence of events a kind of Old Testamentstyle annihilation of oppressors. Several individuals showed me Old Testament verses in which God decided that one group or individual deserved blessings or victory and another did not. They considered these scriptural situations to be analogous to the recent, local conflicts that secured the Protestant "victory" over Muslims in Phase Three.

The view that it was God who decreed victory and defeat, however, offended other Protestants when it was invoked to explain the Muslim "victories" of Phases One and Two. One Central Sulawesi Protestant Church (GKST) leader was offended because he understood Governor Paliudju's April 18, 2000 statement to imply that Phase One and Two damages against Christians were wrought by God and so should not be avenged by human beings. ${ }^{112}$ In that case, the Protestant minister was outraged that a Muslim politician would insinuate that God's rules were prevailing among mankind during the communal conflicts. On the other hand, rather than distancing themselves from all acts of violence, the same ministers from the GKST synod in Tentena seemingly defended local Protestants involved in heinous Third Phase attacks on Muslims, such as the one at Kilo Nine. ${ }^{113}$ The Toba Batak director of the GKST Crisis Center in Tentena wrote that efforts were being made to scapegoat and label as rioters "Poso citizens who only struggled to seek justice in their ancestral land" (anggota masyarakat Tana Poso yang berjuang mengupayakan keadilan di tanah leluhurnya). ${ }^{114}$

Although the religious focus on Holy Wars and Acts of God, like the media focus on headhunters and criminal provocateurs, eclipses group conflicts over resources, it is clear that access to land will be gained or lost by particular ethnic groups in regional

\footnotetext{
${ }^{110}$ Reen et al., "Crisis in Poso."

111 These individuals knew Tibo was a Catholic and meant "Christian" in the generic sense.

112 Rinaldy Damanik, "Pernyataan Sikap Crisis Center GKST Mengenai Kerusuhan Poso (Sulawesi Tengah)," Eskol-Net, June 18, 2000, section 3.4 .

113 Reen et al., "Crisis in Poso."

114 Damanik, "Pernyataan Sikap Crisis Center," section 5.4.
} 
conflicts such as Poso's. Hence, the use of terror tactics and gruesome imagery by both Central Sulawesi citizens and government forces becomes potentially strategic: to trigger refugee flight or justify military intervention. Most Protestant refugees escaped to more securely Protestant areas, such as Tentena, Napu, or Manado, while most Muslim refugees fled to more securely Muslim areas such as Palu, Parigi, South Sulawesi, and Java. Thus, while such violence may look and feel like an expressive manifestation of anger or a millennial moment defining God's will, no one should overlook its territorial and relational causes as well as consequences. ${ }^{115}$

To add further on the question of why western Central Sulawesi Protestants and Muslims were better able to contain provocations and maintain peace, it is useful to compare Salvation Army leaders' pronouncements to those of GKST leaders in Poso. Most Salvation Army leaders continued their usual declarations that "People make plans, but it is God who arranges everything" (Manusia berencana tetapi Tuhan yang mengatur semua), "everything is in God's hands" (semua di dalam tangan Tuhan), and "we humans must just pray" (kita manusia harus berdoa saja). These phrases encourage congregations not to interfere with unfortunate events other than to pray. This fatalistic attitude, combined with interdenominational Protestant rivalries and few kinship relations with Pamona people, prevented most Palu area Protestants from viewing attacks against Poso Protestants as actions they should avenge personally. In short, while Protestant churches worked to unite community groups within a single mission field, sectarian competition created geographic boundaries that divided those religious unions from one another. It is also interesting to note that some Hindu Balinese migrant enclaves situated in the midst of devastated Muslim and Protestant areas around Poso remained unharmed, demonstrating the precision of the Muslim and Protestant assaults with regard to their ethnic and religious targets. ${ }^{116}$

Although criticized by some observers for thinking too exclusively about their own membership, by July 2000, Salvation Army congregations in Palu were collecting rice donations for Poso refugees without regard to religious affiliation. In another measure showing belated concern about their image with local Muslims, Salvation Army leaders temporarily halted construction on half-built churches in Palu, saying that it would be improper to continue such projects while refugees were suffering. More conciliatory efforts by Christian and Muslim groups throughout Sulawesi will be needed to stop the settling of old scores and begin the remembering of common needs.

\section{Patron-Client Ties, Struggling Regions, and the Need for a Renewed State}

There are several lessons from Sulawesi history that can be recast to aid understanding of the Poso conflicts. First, we should consider the relevance of the historical tension between territorial and human ("ethnic" and "religious") bases of political geography that has been observed since the colonial era. Ethnic identity among indigenous Central Sulawesi groups is strongly landmark based, which is why

115 Danilyn Rutherford, "Waiting for the End in Biak: Violence, Order, and a Flag Raising," Indonesia 67 (1999): 39-59; and Nils Bubandt, "Violence and Doom: Cultural Narratives and the Dynamics of Violence in Maluku," paper presented at the "Beginning the 21st Century" conference, Makassar, August 1-4, 2000.

116 I am grateful to Tim Babcock for bringing this observation about Balinese hamlets to my attention. 
Pamona and other autochthonous highlanders are concerned over alienation from their ancestral land, which has been increasingly occupied by immigrants from the South Sulawesi and Javanese diasporas. Second, the basis of leaders' authority always has been communal, rather than territorially, bounded, which is why Pamona leaders in Poso could readily mobilize fellow GKST members in Tentena, and why similar networks, such as Al-Khaira'at, were mobilized in coastal Muslim communities east and west of Poso. As discussed earlier, these religious divisions were strengthened by the intentional or unintentional actions of the state throughout the twentieth century, from the Dutch colonial through the New Order administrations. Third, local leaders always have gained and held prestige based on their ability to broker economic deals with outsiders. Formerly, desirable resources for highlanders came through exchange with coastal kingdoms, and vice versa. Later, missionaries and religious organizations served to broker many economic exchanges. Now the biggest prize money comes from Jakarta, with some resources channeled through the provincial capital of Palu, which is why both Pamona and Bugis-affiliated leaders feel that they cannot lead their communities effectively without representation of some kind in the Poso Regency office.

Thus, we can reconsider the conflict phases in Poso as events involving patronage politics that mobilized groups who harbored pre-existing resentments about ethnic disparities in land and political control, and who subscribed to ideologies divided along twentieth-century religious currents (aliran). Phases One and Two demonstrate the increasingly state-supported, political strength of Bugis-affiliated Muslim migrants to Poso City, who were reinforced by coastal Muslims allies, as it compared to the declining political strength of Protestant Pamona. Christians found themselves unable to get their candidates elected, saw their neighborhoods burned, and were unable to obtain the security they sought from the police and judicial authorities. Phase Three represents a vendetta likely organized by urban Pamona, which was supported by the irredentist sentiments of their rural GKST allies as well as several Catholic immigrant fighters. Both patterns of attack-Muslims against Protestants and Protestants against Muslims-warrant more detailed analysis of the economic struggles and geographic networks involved.

The fighting began each time between Pamona-affiliated Protestants and Bugisaffiliated Muslims in Poso City. Urban violence escalated and spread as these factions called in their allies. Muslims came from the coastal towns to the east and west of Poso, and GKST Protestants came from the interior to the south towards Tentena. Fighting ultimately spread along the roads into the rural districts, especially just south of Poso, where both Javanese Muslims and Flores Catholics became involved. Beyond their respective Muslim or Christian ideologies, what political interests and economic transactions tied these different ethnic groups together?

In Poso City, Pamona and Bugis-led factions struggled for political control over the regency administration and the economic development perquisites which that political office entailed. Muslim factions won that competition, although the winning individuals were not the original Muslim contenders. Outside of Poso, especially to the south, immigrant Muslims, mainly Javanese and Bugis, increasingly competed with indigenous Protestant subsistence farmers to gain land for cash crops. The networks between the urban and rural groups were economic as well as religious. Rural Muslim 
immigrants, of mainly Javanese and South Sulawesi heritage, marketed their cash crops to Poso traders, such as those in Kayamanya. Kayamanya is only a few miles directly downstream from Sintuwu Lemba (Kilo Nine), and the patron-client connection between the two communities reportedly is strong. Similar exchange relations, as well as direct kinship ties, linked Muslim Poso neighborhoods to towns east towards Ampana and west towards Parigi. Among all these communities, Islamic organizations such as Al-Khaira'at broadened the network beyond strict relations of ethnicity.

Among Pamona and other Protestants in the towns around Poso and between Poso and Tentena, the connections are even more straightforward. Individuals were tied to an ideology of a common ancestral homeland. This nativist ideology was elaborated, and the human network expanded, through the GKST church organization. The least obvious factor is still the participation by Catholic migrants from Flores to the Poso-Morowali regions. Somehow Lateka (now deceased), the brother-in-law of Parimo (now deceased), became connected with Tibo and his accomplices. Most likely, money, combined with religious passion, fueled the Third Phase vendettas from which Poso has yet to recover. At this point, now sadly deemed Phase Four, the legacy of uncontained violence has fostered widespread distrust, a seductively profitable homemade weapons industry, and levels of local anxiety that make many people look outward for some hope of state relief and balanced mediation.

The 1999 Regional Autonomy Laws asserted that the rights, origins, and customary traditions of villages and regions are to be respected, without saying exactly how that is to be done in multi-ethnic areas experiencing just the opposite lessons during the Suharto period. The DPR's Commission on Security Affairs recently backed a plan to solve Poso's disturbances with a return to customary law. ${ }^{117}$ Yet, ancestral rules for dispute settlement can only work where the rules are consensually authorized. This is unlikely to be the case in Poso among Bugis, Pamona, and Javanese, among many others. National legal solutions also are difficult in a politically unstable nation short of cash and reliable systems of justice. Should the physical and political displacement of indigenous peoples be retroactively redressed? Should previously favored groups who obtained development jobs or appropriated the ancestral lands of others be suddenly stripped of their gains? Such cases are not easily adjudicated because migrating groups, such as Bugis, Javanese, Minahasans, or Madurese, often are just as much subjects of state development programs and elite business interests as the Pamona, Kaili, or Dayak whom they displace. Clearly, it is easier to recognize the state's historic culpability and current infrastructural problems than it is to find communal conflict solutions without adequate and neutral state security and justice. Yet, neutral security forces, grassroots bilateral mediation, and a vision of a more level playing field are what is needed.

In July, 2000, I asked several Central Sulawesi citizens what they thought when President Suharto stepped down. Most said they had at first been elated by the resignation. Then some people commented that, "for thirty-three years under Suharto, Indonesia was a peaceful place, but now under President Wahid there are disturbances everywhere." The resignation of President Suharto simultaneously removed both a legitimate target of popular anger and the military control mechanism that prevented

117 “DPR Backs Plan to Use Customary Law in Poso," Jakarta Post, August 6, 2001. 
expressions of, and regional solutions to, communal dissatisfaction. Indonesians came to distrust the legal-military bureaucracy and doubt the state's ability to create the security and justice needed for regional reconciliation. Vigilantism prevailed, and religious symbolism overshadowed more complex economic realities in places such as Poso, where the actions of a few political leaders or "big fish" led to severe losses for tens of thousands of people. 
